\title{
YAEL RICE
}

\section{PAINTERS, ALBUMS, AND PANDITS}

\author{
Agents of Image Reproduction in Early Modern South Asia
}

\begin{abstract}
The main question that this essay attempts to answer is why and how multiple eighteenth- and nineteenth-century manuscript ateliers collected and copied (in some cases, repeatedly) painting designs intimately associated with album paintings produced at the seventeenth-century Mughal court. The study argues that the agents of image reproduction, in these instances, find material, corporeal realization in the recursive operations that South Asian painters employed in reproductive pictorial practices rooted in distilling, outlining, and tracing forms; in the apparatus of the album, a book technology that was at once porous and itinerant; and through such less considered intermediaries as pandits, or Hindu knowledge brokers, who facilitated the widespread copying, circulation, and incorporation of Mughal designs in paint over the course of three centuries.
\end{abstract}

The manuscript painters who served at the royal courts of South Asia in the early modern period copied and otherwise adapted a panoply of images, many of which were copies themselves. Take, for example, the artist Nini's early seventeenth-century rendition of the martyrdom of St. Cecilia after an engraving by the Netherlandish artist Jerome (Hieronymus) Wierix (1553-1619), which today resides in the Victoria and Albert Museum, London (figs. 1, 2). This work exemplifies how painters selectively and creatively translated different media through the acts of tracing contoured lines and colorizing images. The same can be said of another version of the same composition in the Maharaja Sawai Man Singh II Museum, Jaipur, which likely post-dates Nini's work by more than a century (fig. 3). The many commonalities enjoyed by the London and Jaipur paintings-for example, both are paired with illuminated fragments of calligraphic poetry, and they share similar color palettes-indicate that the former was very likely the direct model for the latter.

Nini's sustained engagement with Wierix's print may be explained by her employment at the court of the Mughals, a powerful and wealthy Sunni Muslim dynasty of Turko-Mongol origins that ruled over much of South Asia from the sixteenth to mid-nineteenth century. Alongside their ideologues, the Mughal rulers Akbar (1542-1605, r. 1556-1605) and his son Jahangir (1569-1627, r. 1605-27) cultivated an ecumenical ethos in response to the challenges of
QUICK CITATION Rice, Yael. "Painters, Albums, and Pandits: Agents of Image Reproduction in Early Modern South Asia." Ars Orientalis 51 (2021): 27-64. 


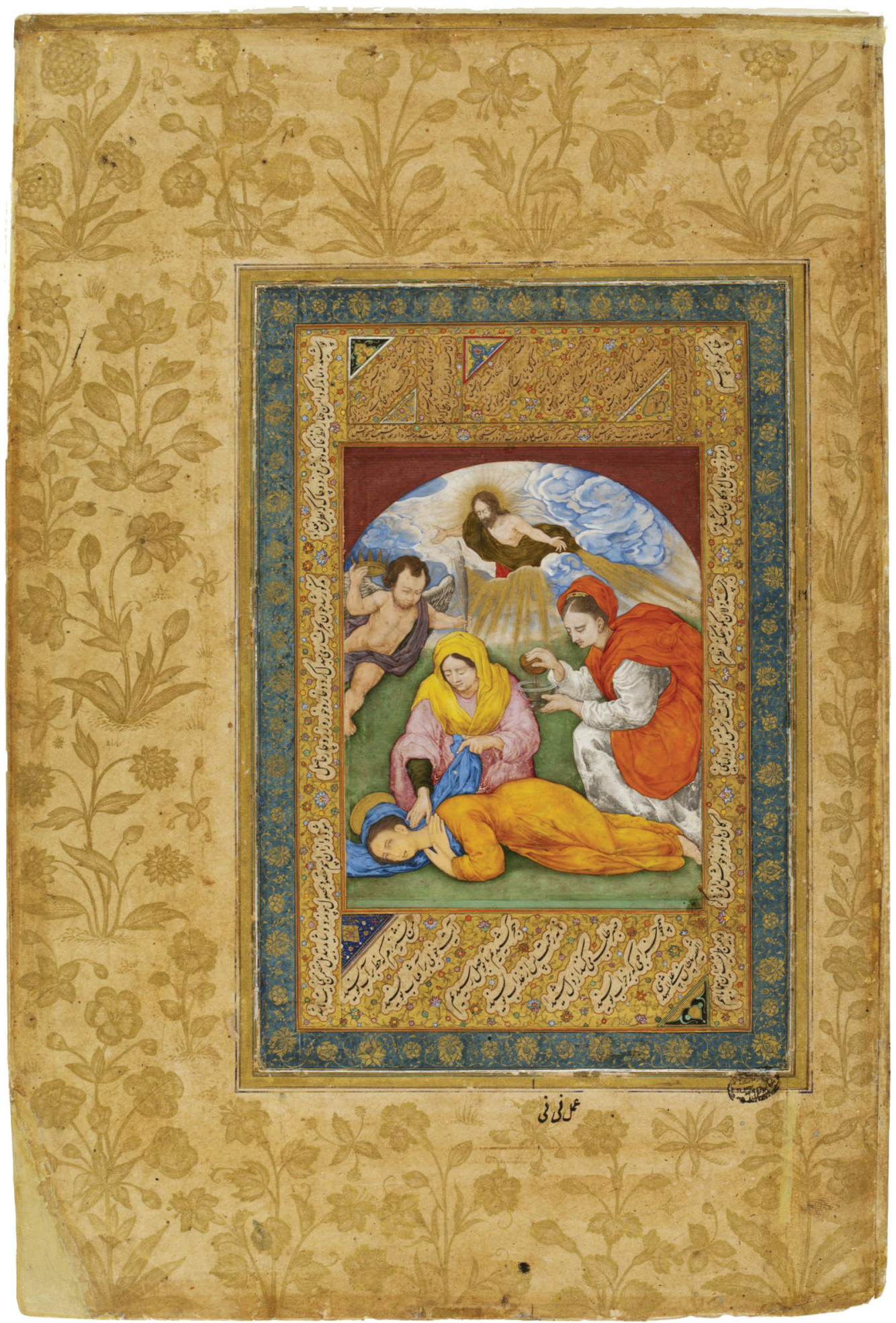

FIGURE 1. Nini (attributed), page from the Wantage Album bearing a painting of the Martyrdom of St. Cecilia, northern India, early 17th century (painting) and 1630s (page). Ink, opaque watercolor, and gold on paper; painting: $13.5 \times 10.4 \mathrm{~cm}$; page: $38.3 \times 25.8 \mathrm{~cm}$. Victoria and Albert Museum, London, IM.139A-1921 


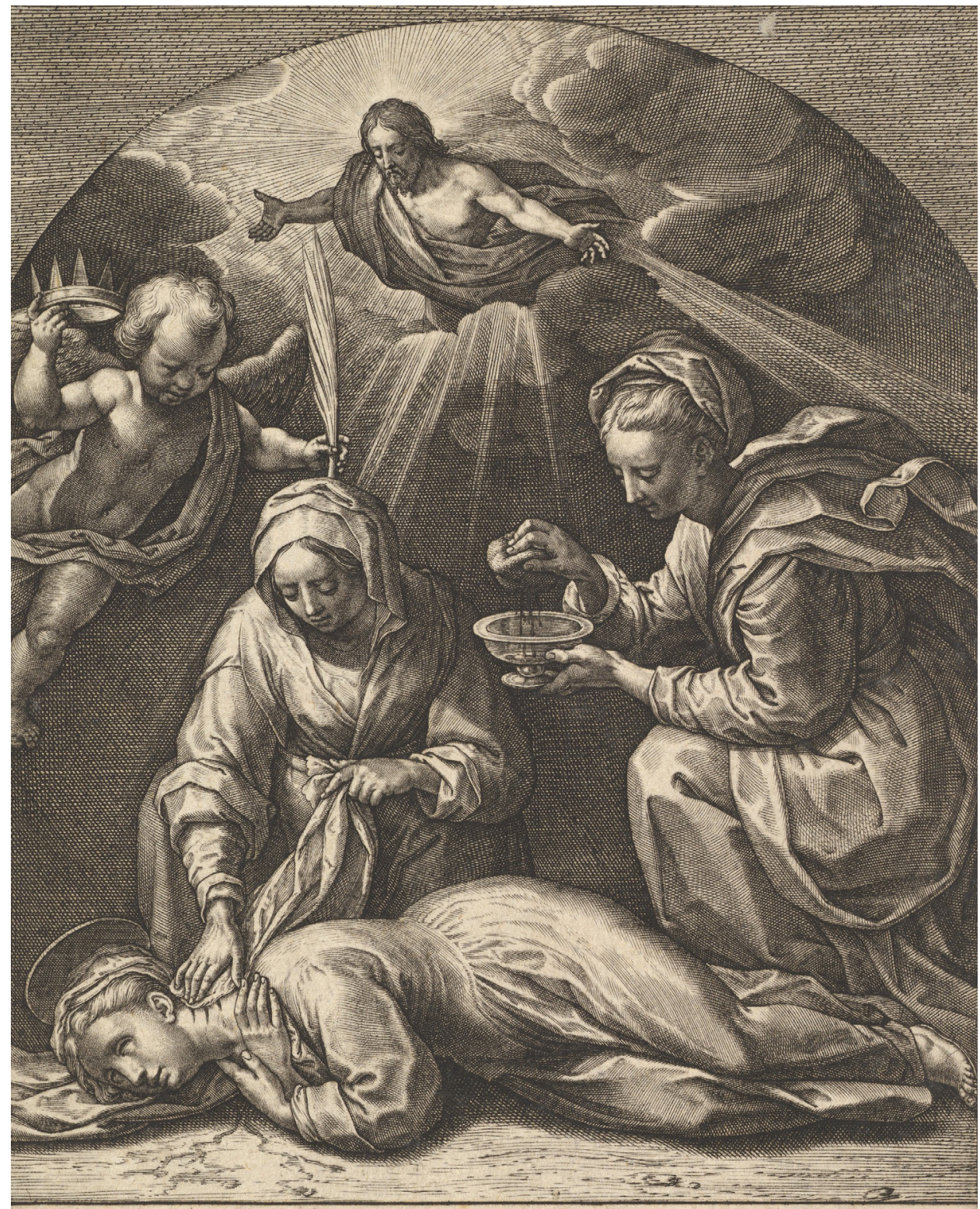

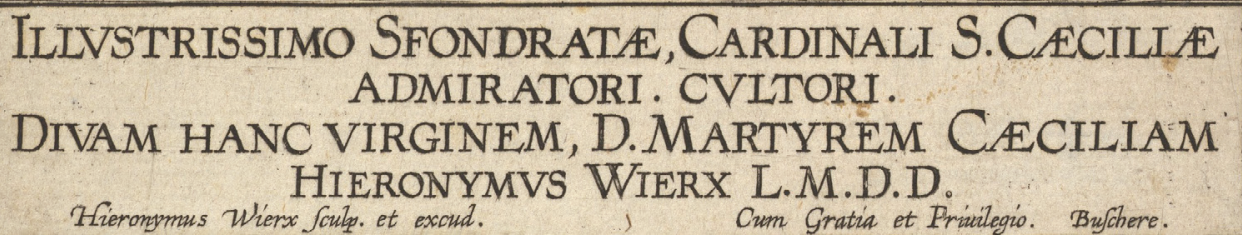

FIGURE 2. Jerome (Hieronymus) Wierix (1553-1619), Martyrdom of St. Cecilia, Netherlands, ca. 1599-1605. Engraving, plate: 15.2 x $10.8 \mathrm{~cm}$. Metropolitan Museum of Art, New York, 2012.136.700

ruling over a largely non-Muslim populace. Their assiduous collection of European works of art and patronage of paintings made after them was but one dimension of this larger project. The mounting of these works in composite albums known as muraqqa's (from the Arabic for "patched" or "mended") primed them to be received as thoroughly Mughal expressions. Furthermore, studies like Nini's appeared alongside Iranian, Central Asian, and South Asian paintings, drawings, and calligraphies-many of these also copied from earlier models-to present a vision of a universalizing empire poised to incorporate and assimilate all in its wake. Neither Jahangir, whose regnal name means "world-taking," nor his son and successor Shah 
Jahan (1592-1666, r. 1627-58), whose title means "emperor of the world," succeeded in conquering the globe, but the albums produced at their courts did, in a way.

In the mid-1650s, the Dutch artist-entrepreneur Rembrandt van Rijn (1606-1669), based in Amsterdam, produced his own copies of Mughal album paintings, some of which only could have been executed two or three decades prior. It is not only the rapidity and geographical breadth of the circulation of Mughal albums that is so astonishing but also the long-standing resonance of these albums and their contents. ${ }^{1}$ Indeed, at least one of the Mughal works that Rembrandt copied eventually travelled to Vienna, where members of the Habsburg family craftily mounted it and other album paintings of South Asian origin in highly ornamented, curvilinear frames on the walls of the Schloss Schönbrunn's Millionenzimmer during the second half of the eighteenth century. ${ }^{2}$ In yet other instances, Mughal albums that Nader Shah (r. 1736-47), founder of the Iranian Afsharid dynasty (1736-96), likely looted from the imperial treasury in Delhi in the mid-eighteenth century landed in Iran, and parts of these books eventually made their way to St. Petersburg, Berlin, and beyond. ${ }^{3}$ Like these examples, the St. Cecilia image in London (see fig. 1) also wended its way westward. Indeed, it is one of the thirty-three muraqqa' folios bearing both paintings and calligraphies that Lady Wantage (1837-1920), who acquired the collection from her father, a banker and politician, in the 1860s, bequeathed to the Victoria and Albert Museum in 1921. ${ }^{4}$

The origins and trajectories of the St. Cecilia image in Jaipur (see fig. 3), on the other hand, bespeak the rich and complex lives that album paintings enjoyed exclusively in South Asia. Unlike Nini's painting, this work most likely was made in one of the manuscript workshops of Awadh, a Mughal suba (province) in northern India, which in the eighteenth century was ruled by a lineage of hereditary nawabs (deputy governors) of Iranian Shi'i origin in all but name. The Mughals' political decline over the course of the eighteenth century contributed to the empire's fragmentation, but it also spurred the rise of semi-autonomous rulers, like the nawabs of Awadh. As the balances of power shifted, South Asian, Iranian, and European bureaucrats and elites flocked to alternative centers of influence in Awadh and in the other thriving Mughal subas of Orissa, Bihar, and Bengal, followed by Mughal and other manuscript painters and specialists of the book, who depended upon the patronage of elites for their livelihoods. The new workshops that arose across India over the course of the eighteenth century not only generated fresh album paintings wholesale but also drew upon and incorporated the older works (including finished paintings, incomplete studies, and tracings) that were in the possession of collectors and artists. A market for the sale and purchase of Mughal albums and album pages also thrived, as European and South Asian elites alike sought to incorporate these materials, as well as their copies, into their own collections to cement meaningful links with the powerful sovereigns who preceded them. ${ }^{5}$ It was likely under these circumstances that the St. Cecilia image now in London landed in Awadh, where at least one copy of it was made. Yet these two related paintings-one dating from the early seventeenth century, the other created more than one hundred years later-did not remain together; where the Mughal version followed a trajectory that brought it eventually to London, the Awadhi copy instead landed (and remains) in Jaipur.

The main question that this essay attempts to answer is why and how pictorial compositions first created at the Mughal court during the seventeenth century were later copied (in some cases, many times over) in non-Mughal workshops and then circulated widely and incorporated into yet other workshops and book contexts. In attending to the matters of copying and reproduction, the essay builds upon recent studies of the prevalent "practices of reuse" among early modern South Asian court painters, in which, for example, Molly Aitken 


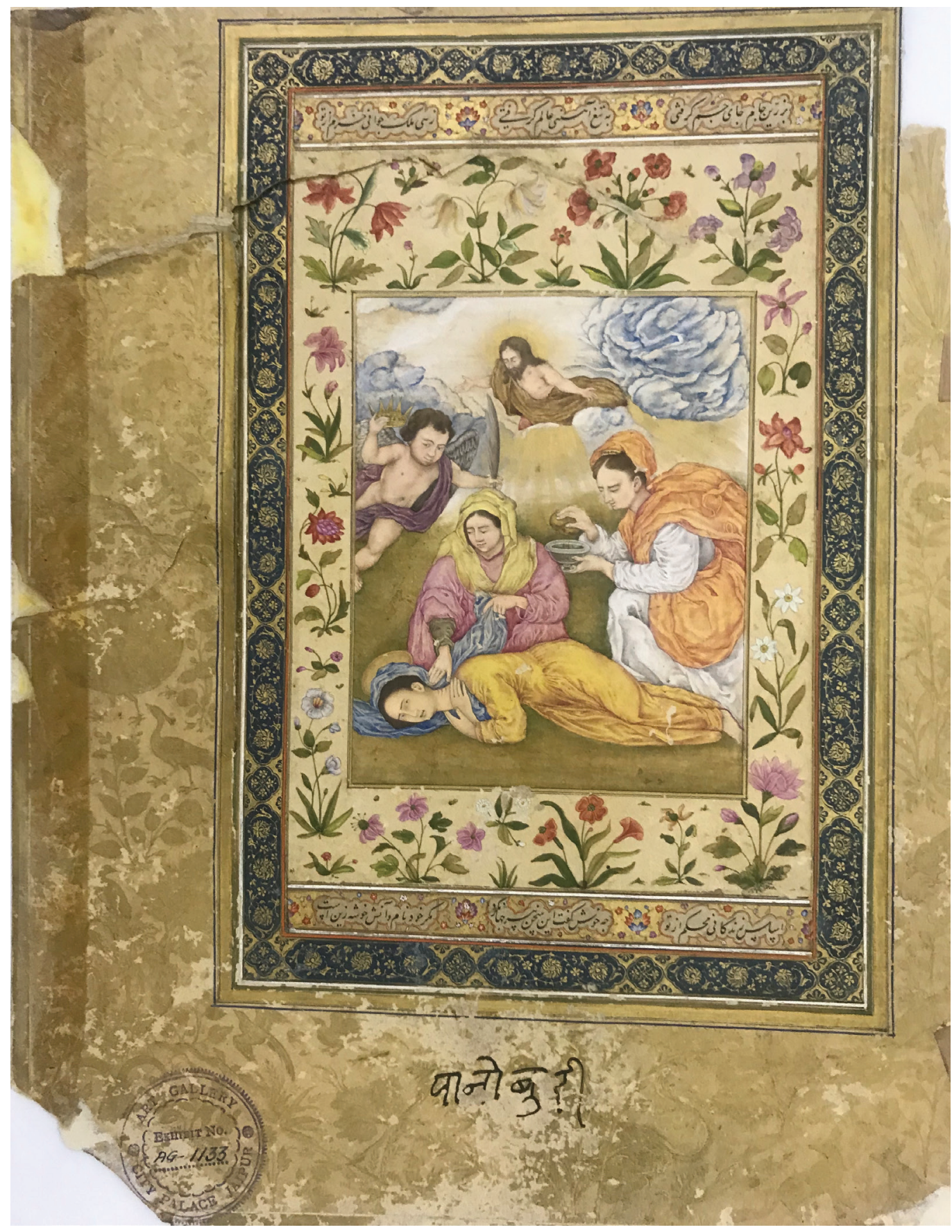

FIGURE 3. Album page bearing a painting of the Martyrdom of St. Cecilia, India (probably Awadh), late 18th century. Ink, opaque watercolor, and gold on paper; painting: $12.9 \times 10.2 \mathrm{~cm}$; page: approx. $38 \times 26 \mathrm{~cm}$. Maharaja Sawai Man Singh II Museum, Jaipur, AG 1133. (c) Maharaja Sawai Man Singh II Museum Trust

has proposed that "painters reused with a strong sense of the past, of respect for past masters, of competition with one another, and of pride in the skills and invention they could bring to their tradition." ${ }^{1}$ Here, however, these interventions are extended to consider how the agents of image reproduction, in these instances, also inhered in the recursive operations that South Asian painters employed in reproductive pictorial practices rooted in distilling, outlining, and 
tracing forms; in the apparatus of the album, a book technology that was at once porous and itinerant; and through such less considered intermediaries as pandits, or Hindu knowledge brokers, who facilitated the widespread copying, circulation, and incorporation of Mughal designs in paint over the course of three centuries. ${ }^{7}$

This essay addresses examples of seventeenth-century Mughal portraits and animal studies that later artists also copied in large numbers, and which non-Mughal patrons then incorporated into their collections. Yet, the images of St. Cecilia remain a touchstone because they allow us to track in definitive, material terms the flow, replication, and incorporation of Mughal paintings from the Mughal courts to Awadh, Jaipur, and, finally, London. The close examination of these materials and their contexts also has revealed the significant role that one Nandaram Pandit-an important powerbroker who enjoyed privileged access to both South Asian and European elites in eighteenth-century Awadh-likely played in negotiating the circulation of these St. Cecilia images. Thus, while this study proceeds in large part chronologically, moving from the seventeenth-century Mughal court to eighteenth-century Awadh and Jaipur, we will return repeatedly to the St. Cecilia album painting in London, and the larger group of album pages in the Victoria and Albert Museum to which it belongs, to probe the broader vectors of copying, collection, and dispersal that facilitated the repeated duplication and translocation of this image for three centuries.

\section{Embodying Design: The Copied Image at the Mughal Court and Beyond}

Comparison of the St. Cecilia in London alongside Wierix's engraving leaves little doubt that the Mughal painter Nini examined the European print closely (figs. 4, 5). Not only do the two images share approximately the same dimensions but their compositional structures, even down to the hemispherical shape of their upper registers, are strikingly similar. We do not know whether the particular impression of Wierix's print that Nini studied had arrived at the Mughal court already with colors added; in any case, she opted to paint her version of the martyrdom scene in brilliant hues of orange, red, blue, and green, as well as gold. Among the other adjustments are her reworking of St. Cecilia's face, in particular the elongation of the nose and the increased definition of the eyebrows and pupils. Far from being a product of mere slavish imitation, Nini's rendition suggests that a more inventive and capacious rationale motivated this reproductive exercise.

The copying of pictorial compositions had, in fact, been commonplace for centuries among the painters employed at the royal courts of the larger Persian-speaking, or Persianate, ecumene. ${ }^{8}$ In these instances, acts of duplication seldom amounted to perfect replications, for one of the main goals of copyists was, firstly, to establish their awareness-and, ideally, mastery-of an established pool of compositions; and, secondly, to enhance in subtle ways the original design, and thereby insert their own unique renditions into a longer chain of artistic performances on the same theme. These operations presumed the existence of a broader, imagined community of makers and connoisseurs who alleged ownership of a single, shared stable of forms. These forms depended upon insider knowledge, both on the part of the artist and the viewer, to resonate as both homages to and confrontations with an established canon.

For the Mughals, the patronage, reproduction, and collection of canonical compositions provided the means for this Turko-Mongol dynasty transplanted to South Asia to claim membership in a distinguished Persianate cultural lineage. It is within this framework that the Mughal painter Nanha (active 1582-1635) produced a composition featuring fighting camels-a subject commonly treated in Persianate drawing studies-during the early 


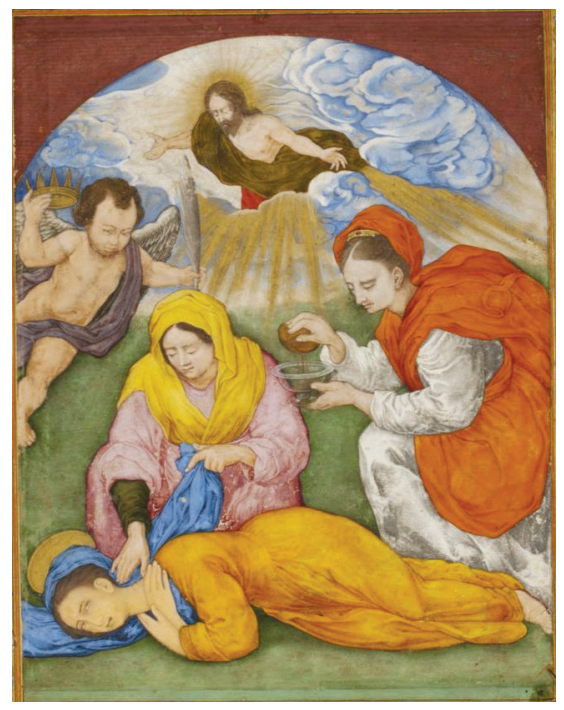

FIGURE 4. Detail of figure 1

seventeenth century. ${ }^{9}$ Not long after its creation, Nanha's work was mounted on the left-hand side of an album opening, facing another study of the same subject credited to Bihzad (active 1450-1535), a Timurid-Safavid artist who enjoyed legendary status even during his own lifetime, and whom Emperor Akbar's chief ideologue, Abu'l Fazl (1551-1602), had identified as a benchmark of artistic prowess and aptitude (fig. 6). ${ }^{10}$ The mounting of these two camel studies on opposite pages-a juxtaposing arrangement that encouraged close comparison-in an album originally assembled for Jahangir implicated the Mughal sovereign in the revival of an artistic chain of production tied to Herat during the Timurid Empire (1370-1507) and Tabriz in Safavid Iran (1501-1736). Even the Persian inscription appended to Nanha's study, written by Jahangir himself in AH 1017/1608-9, centers the emperor and his acts in its reference to the "work of the master Bihzad" (kar-i ustad Bihzad) that "the artist Nanha saw and, according to the emperor's order (hasb al-hukm), copied." Note that the painting associated with Bihzad, rather than Nanha's work, is emphasized in this imperial inscription. Nanha, in this case, functions as a conduit to the artist Bihzad and, hence, to a genealogy of artistic mastery with connections to Safavid Tabriz, Timurid Herat, and beyond.

Yet, as the evidence of Nini's copy of Wierix's St. Cecilia reveals, Mughal artists also drew upon the established practices of copying to reproduce-and thereby incorporate into the imperial pictorial repertoire-compositions that had no precedents in the Persianate canon. In addition to copying European works, court painters also made replicas of portraits and animal studies of relatively recent origin. One such example is a distinctive design for a mallard, which Mughal artists reproduced on at least three separate occasions during the seventeenth and eighteenth centuries (figs. 7-9). ${ }^{11}$ In these cases, the mallards' contours and coloring are roughly the same, but their settings and scales vary widely: in one image, the male duck is depicted with a companion in a hilly setting; another features the mallard alone; and the final example, attributed (probably erroneously) by a Persian inscription in the lower margin to the painter Dalchand, shows a more diminutive version of the mallard, also outdoors, and this time joined by images of a peri (fairy) and a haloed Emperor Jahangir. These examples underscore the elasticity of the artists' copying enterprise, wherein a single form could be sized smaller or larger and contextualized in any number of ways so as to produce novel iterations that all, nevertheless, incorporate the same fixed design. 


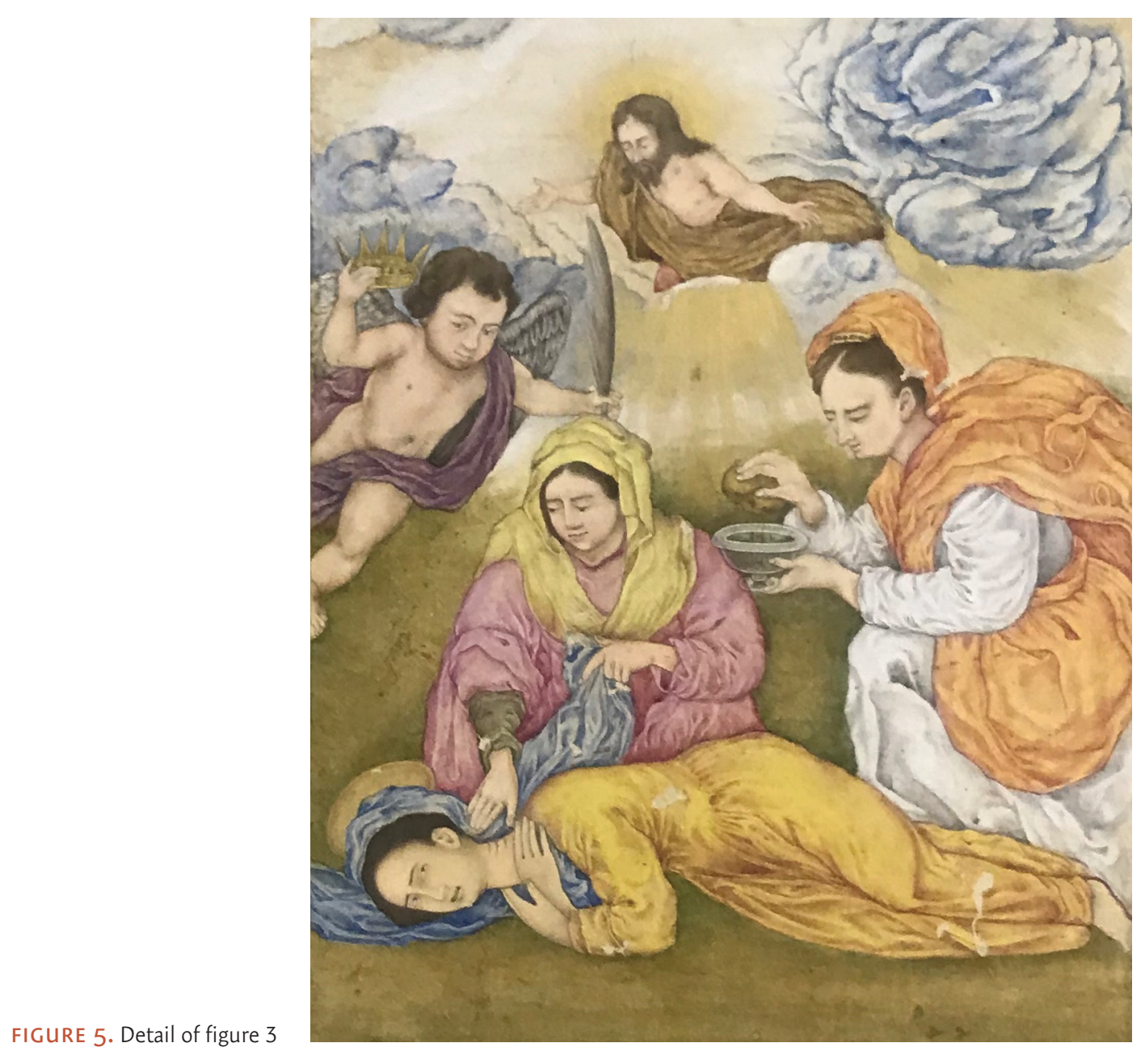

Mughal artists frequently targeted portraits, in particular, in their copying campaigns. Indeed, the image of Jahangir that accompanies the mallard and the peri had been recopied and resituated on numerous occasions by the time that this work was created during the 1620s. Two examples, one painted during the early seventeenth century and the other around the 1630s, reveal how earlier artists standardized this design during the period in question (figs. 10, 11). Once again, the copying operations deployed in these instances did not require the precise replication of every aspect of the picture; rather, in each case, the artist reproduced key physiognomic features-Jahangir's facial profile and physique, especially-while altering other contextual details (such as hand gestures and costume) as needed. The figure of Jahangir's father, Akbar, also is repeated in both works, although, unusually, he is depicted as a youthful, bare-chested figure with face shown in strict profile in the earlier of the two paintings (fig. 10). The image type adapted for the emperor eventually would be made to conform with the threequarter portrait orientation that had been the preferred mode in the paintings produced during Akbar's own reign. At the same time, depictions of Akbar post-dating this earlier moment also portray him, almost as a rule, as an elderly man. The image of Akbar in the double portrait from the 1630s (fig. 11) thus accords far better with the standardized depiction of Akbar that artists at the Mughal court and beyond reproduced for centuries after. 


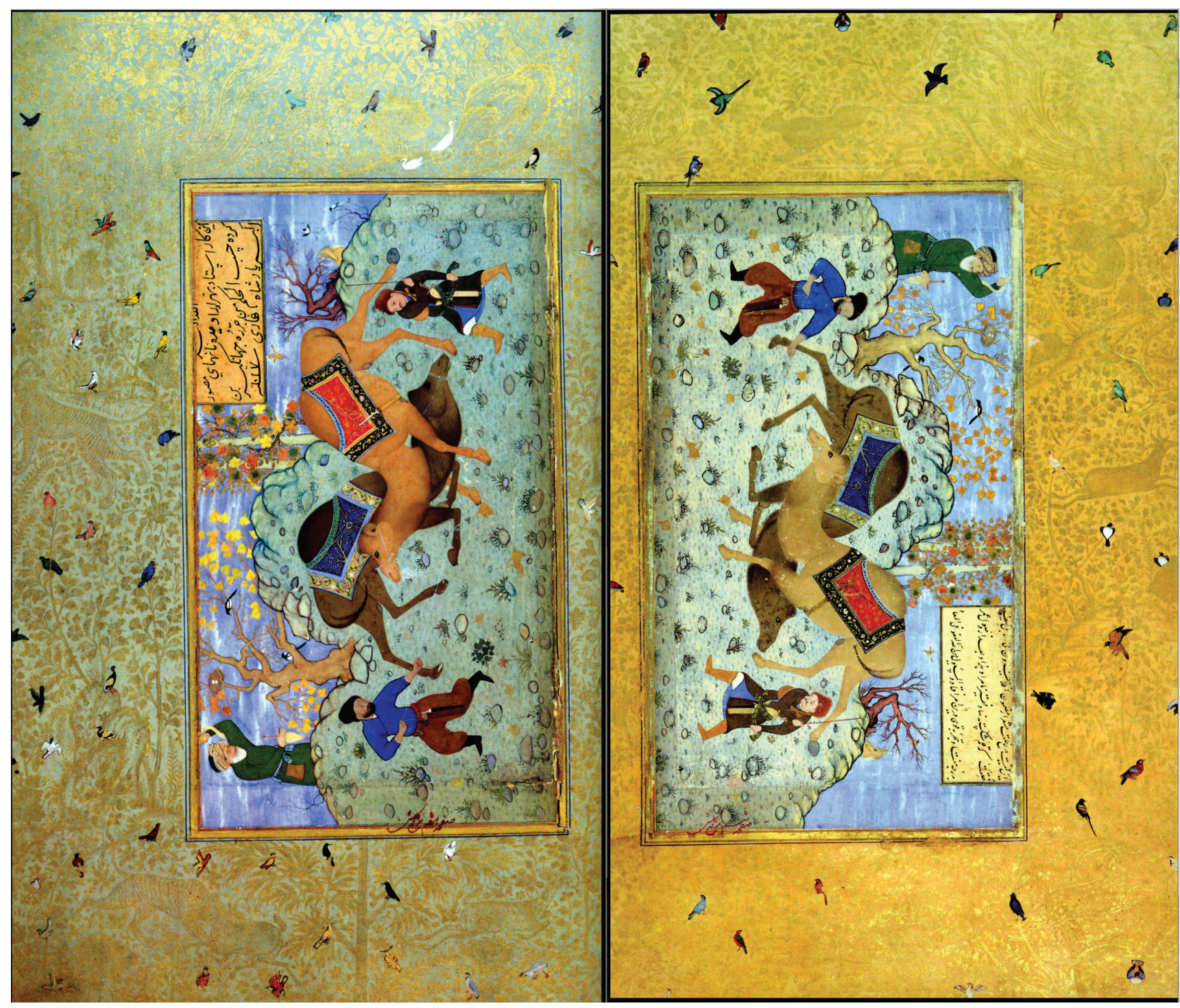

FIGURE 6. Two pages from the Gulshan Album bearing paintings of camel combats, northern India, initially assembled ca. 1599-1618. Each page approx. $42.2 \times 26.5$ cm. Right: Bihzad (active 1450-1535; attributed), first half of 16th century. Ink, opaque watercolor, and gold on paper; painting: $26 \times 16.5$ cm. Left: Nanha (active 1582-1635; attributed), AH 1017/1608-9. Ink, opaque watercolor, and gold on paper; painting: $25.5 \times 15.6 \mathrm{~cm}$. Golestan Palace Library, Tehran, MS. 1668. From Karim Emami and Mohammad-Hasan Semsar, Golestan Palace Library: A Portfolio of Miniature Paintings and Calligraphy (Tehran: Zarrin and Simin Books, 2000), 259, 261; plates 187, 188

In all of these examples of portraiture, the figures are defined by hard and concise, rather than painterly, lines. The Mughal artist's articulation of a subject's body as a discrete, bounded compositional unit-a silhouette-with a fully colored and detailed "skin" of flesh and textiles stretched over it suited an epistemological paradigm that identified exterior nature (surat) as a key to deciphering inner disposition (ma'ani). As an object of physiognomic investigation, the portrait thus distilled and codified the physical appearance of its subject, with line and contour-or what Mughal practitioners themselves termed tarh, meaning design or foundation-functioning as the precipitate locus of the self.

In their creation of portraits, royal painters subjected all, whether emperors, princes, courtiers, allies, or rivals, to an economizing operation that reduced multitudes of bodies to a finite 


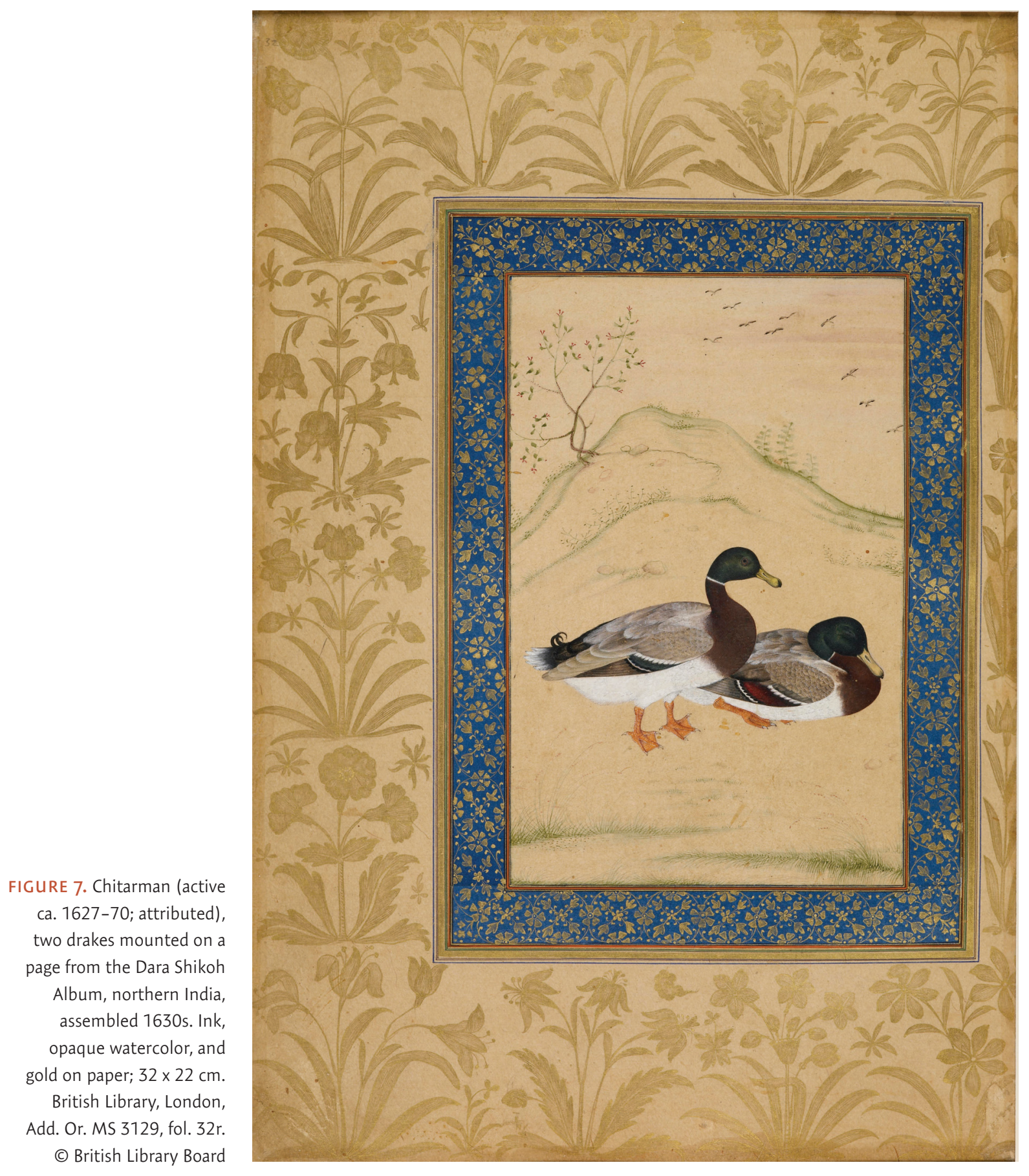

typology. ${ }^{12}$ The narrow-waisted figure, for example, was said to be evocative of a man who was kamar band, "'waist bound up,' [signifying] one ready for action, service and battle."13 This body type was utilized in numerous Mughal portraits of the period, including one of Madhu Singh (1561-1601), brother of the Kachhwaha raja, or king, of Amber; and another of Prince Daniyal (1572-1605), the brother of Jahangir and son of Akbar (figs. 12, 13). Both of these images bear inscriptions crediting their authorship to the same court artist, Manohar (active 1582-1624), and are today mounted in a nineteenth-century Iranian muraqqa' in the Walters Art 


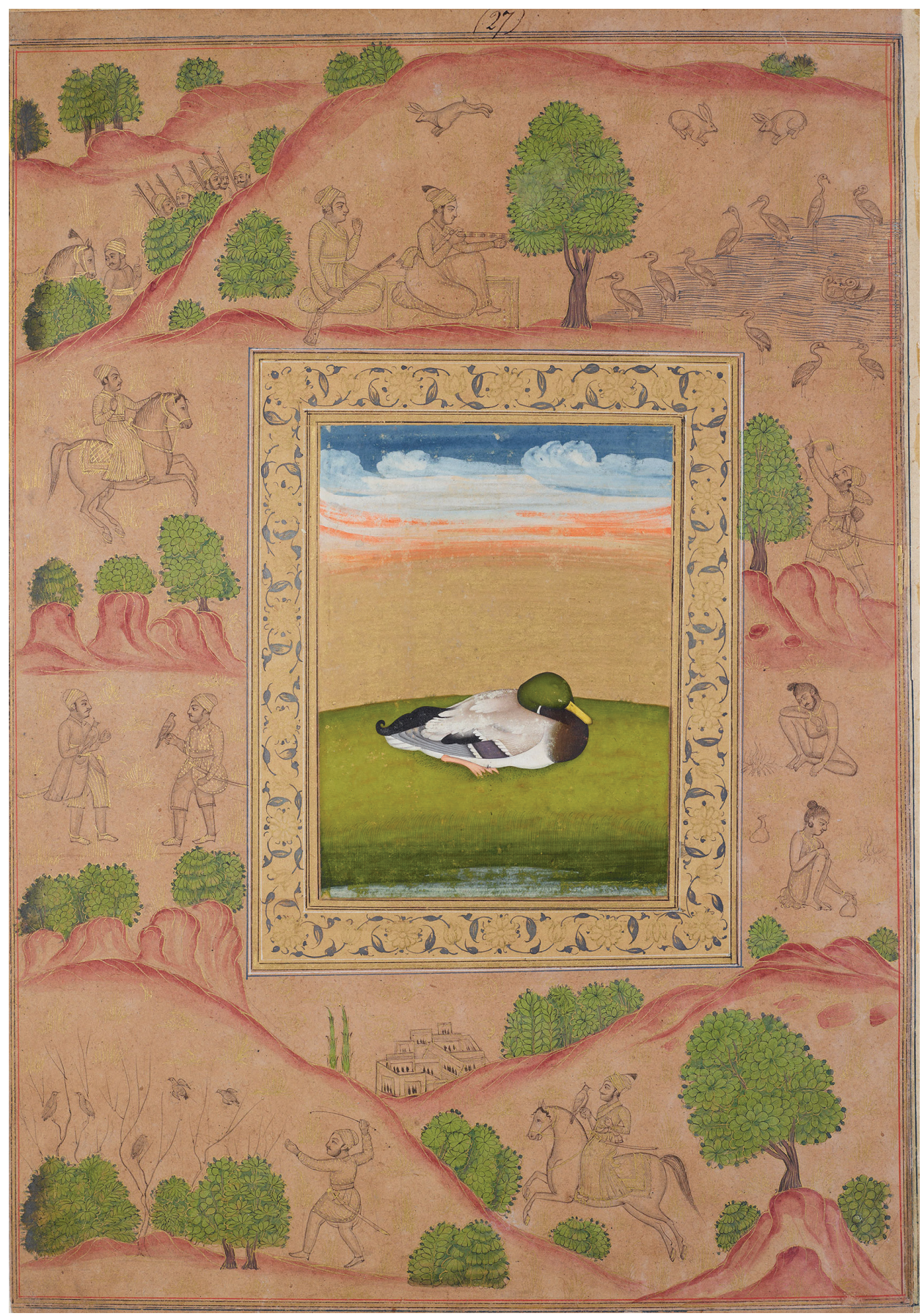

FIGURE 8. Page from the Read Mughal Album bearing a painting of a sleeping mallard, India (probably Murshidabad), second half of 18th century. Ink, opaque watercolor, and gold on paper; painting: $15 \times 11 \mathrm{~cm}$; page: $41.5 \times 30 \mathrm{~cm}$. The Morgan Library, New York, M.458.1v

Museum, Baltimore. In addition to representing the figures with pinched waists bound by tight sashes, Manohar also depicted the two men with thin, wispy mustaches, a grooming preference popularized by Emperor Akbar. Madhu Singh and Daniyal came from seemingly different backgrounds-one was the son of a Rajput king; the other, the son of a Mughal emperorbut they were related by long-standing marital and diplomatic ties. Akbar's marriage in 1562 to the Kachhwaha princess Jodha Bai (Maryam al-Zamani, ca. 1542-1623) had solidified the powerful Kachhwaha clan's rise as subordinated allies to the Mughals, and Madhu Singh, who 
FIGURE 9. Dalchand (active early 18th century; falsely attributed), page from an album bearing a painting of Emperor Jahangir (r. 1605-27) with a peri (fairy) and a mallard, northern India, 17th century

(painting). Ink, opaque watercolor, and gold on paper; $44.5 \times 31.8 \mathrm{~cm}$. Indian

Museum, Kolkata, R.14174/S.102

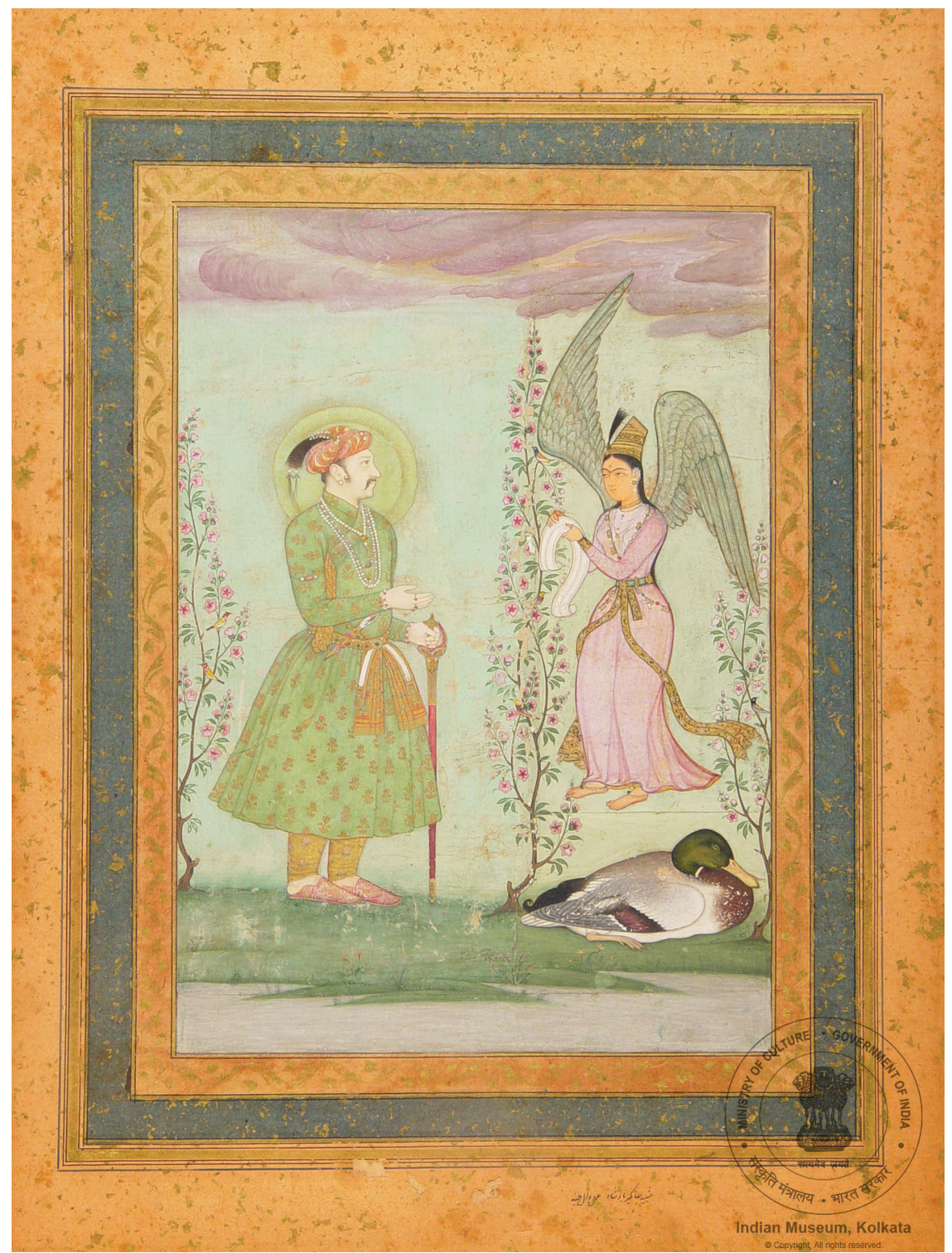

famously served as a loyal general for Akbar, exemplified how fully the Rajput chiefs had integrated themselves into the imperial machine. Daniyal, whom Jodha Bai reared as an infant, was similarly enmeshed in the Kachhwaha-Mughal alliance. Manohar's portrayal of Daniyal and Madhu Singh with strikingly similar builds, physiognomies, and facial features not only amplified their shared familial ties but, even more importantly, allied the two princes with a physical typology that was specific to the Mughal court. Representational similarities like these effectively transformed political and matrimonial affiliations into corporeal phenomena.

In distilling each figure or composition into a codified visual economy of lines, painters reduced their subjects into a legible and easily reproducible combination of representational marks. The expediency of this system allowed artists to transfer the gist, or outline, of a portrait or compositional unit effortlessly from one medial context to another. Illustrating this point, the Mughal artist Manohar's likeness of Madhu Singh found its way onto one of the pages of the Gulshan Album, a muraqqa' initially compiled between 1599 and 1618; here, the 
figure also is accompanied by the aforementioned double portrait of Jahangir and Akbar (see fig. 10), as well as another figure, who very much resembles Prince Daniyal (figs. 14, 15). Visual comparison of the two portraits of Madhu Singh reveals that the image in the Gulshan Album, which must have been reproduced during the early seventeenth century, was copied directly, probably by Manohar himself, from the earlier painting in Baltimore (compare figs. 13 and 15). ${ }^{14}$ Not only are the representations of similar size, but both figures also hold malas (prayer beads) and a leaning stick and are shown wearing similar types of jamas (stitched coats), even down to their coordinated bandhani (tie-dye) linings. The replicable typology of Mughal portraiture and its rootedness in contour and line-based design facilitated (or even encouraged) the straightforward transfer of the subject's likeness from one medial context to another. ${ }^{15}$

More than a tool to expedite the processes of copying and a means to produce physiognomic typologies, however, the Mughal painter's concentration upon outline formed the basis of an embodied workshop practice that underlay the production of all manuscript paintings,

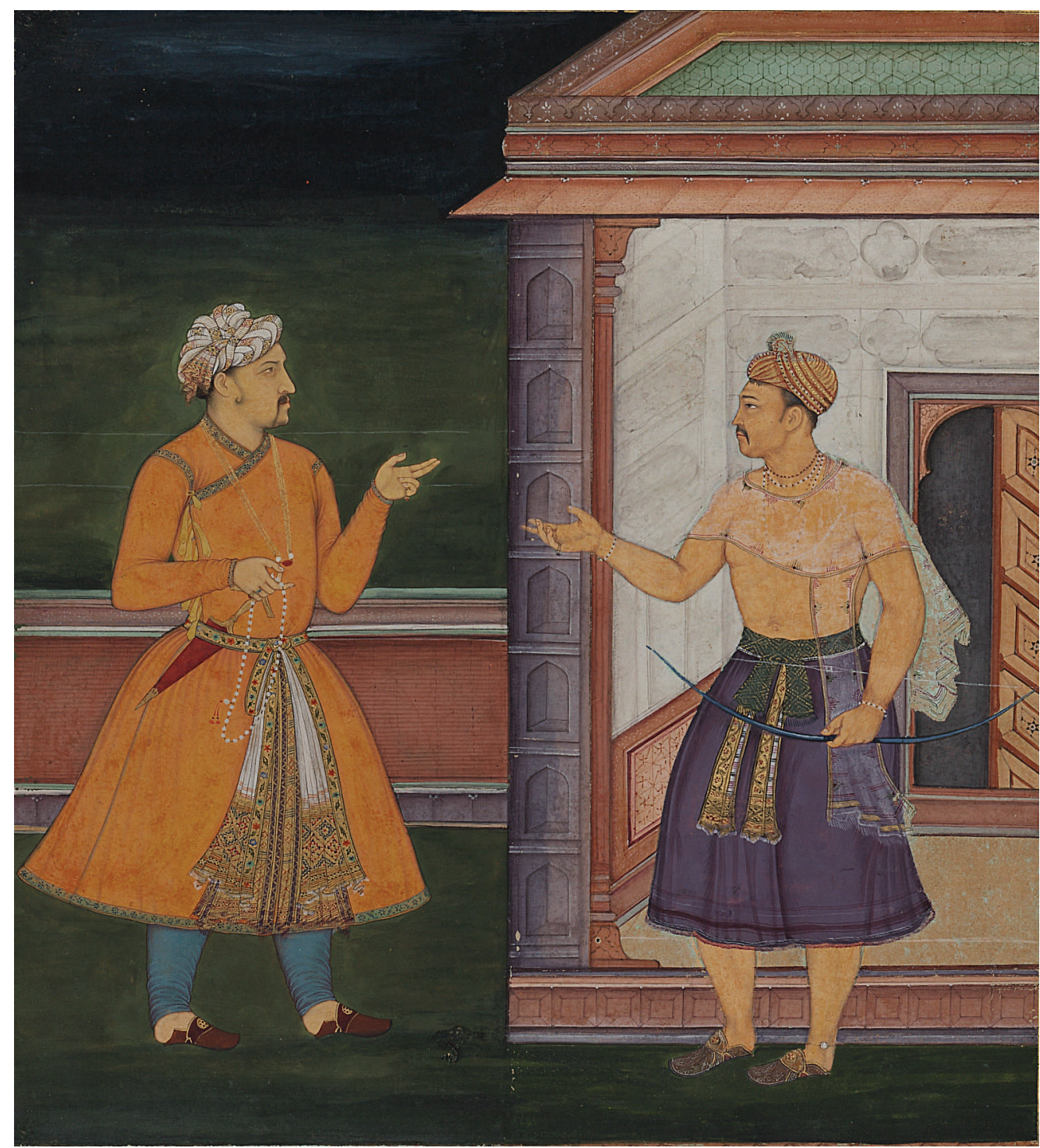

FIGURE 10. Double portrait (detail) of Emperors Jahangir and Akbar (r. 1556-1605) mounted on a page from the Gulshan Album, northern India, early 17 th century. Ink, opaque watercolor, and gold on paper; $14.5 \times 13.1 \mathrm{~cm}$. Staatsbibliothek zu Berlin, Libri picturati A 117, fol. 18v 
FIGURE 11. Balchand (ca. 1596-1640; attributed), page from the Shah Jahan Album bearing a double portrait of Akbar and Jahangir, northern India, ca. 1630s. Ink, opaque watercolor, and gold on paper; 39 $\times 26.3 \mathrm{~cm}$. Metropolitan Museum of Art, New York, 55.121.10.19

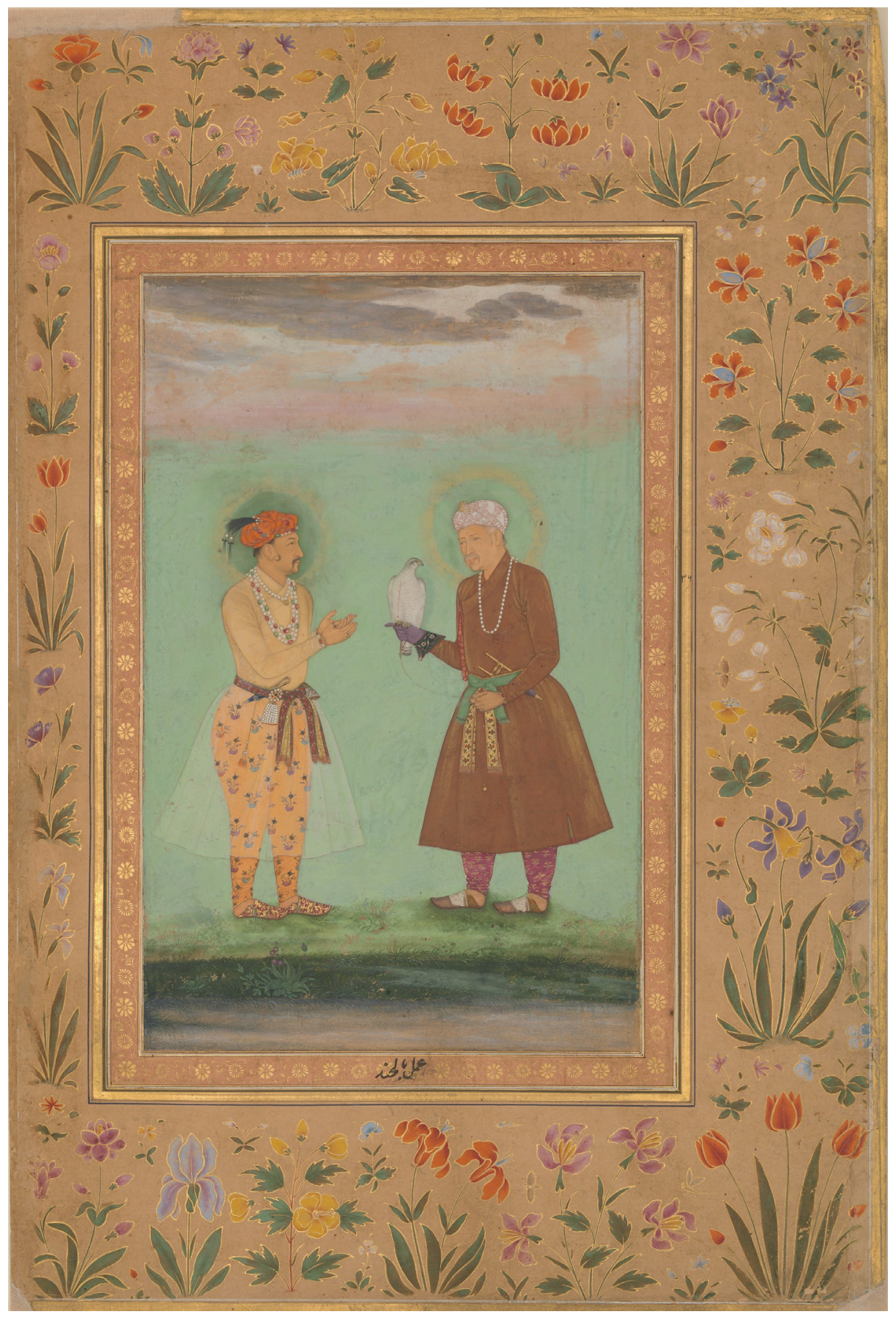

portraits and non-portraits alike. The Mughal image's tarh, or design, represented the concept or idea of the composition, and, as such, operated as the locus of both artistic authorship and the subject's self. Yet, instantiated in the artist's line-based drawing, the tarh also possessed deeply material and technical dimensions. As revealed by an incomplete manuscript illustration, possibly once intended for a copy of the Padshahnama (History of the Emperor), an account of Shah Jahan's reign, the Mughal painter's tarh consisted of precise lines, which the designer or a colorist later would fill in with opaque watercolor (fig. 16). This example 


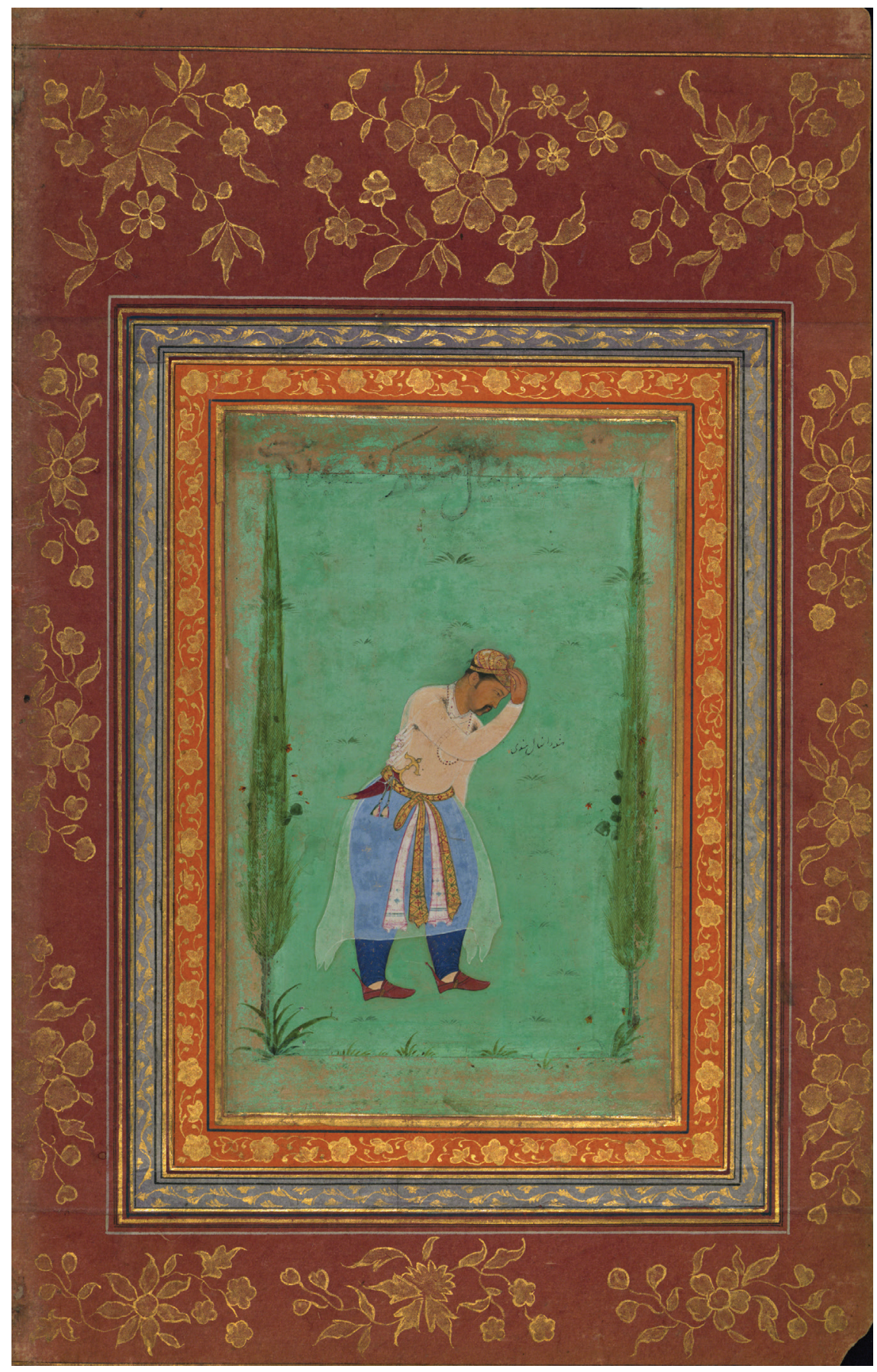

FIGURE 12. Manohar (active 1582-1624; attributed), album page bearing a portrait of Prince Daniyal (1572-1605), northern India (painting) and Iran (page), early 17th century (painting) and 19th century (page). Ink, opaque watercolor, and gold on paper; $29.5 \times 19 \mathrm{~cm}$. Walters Art Museum, Baltimore, W.668, fol. $28 \mathrm{~b}$

shows that the underdrawing was neither a cursory nor loose sketch. It may instead be likened to a delimited template, which, on the one hand, defined its subject's essence, and, on the other, demonstrated the artist's total physical control of pen, brush, ink, and paint. The artist's production of the tarh, in other words, demanded equal parts mental ingenuity, corporeal discipline, and mastery of often unstable materials. Hence, as two early seventeenth-century depictions of Mughal painters preserved in the Gulshan Album show, the assumption of certain bodily dispositions and modes of self-regulation was an integral facet of the painter's designing 
FIGURE 13. Manohar (attributed), album page bearing a portrait of Madhu Singh Kachhwaha (1561-1601), northern India (painting) and Iran (page), early 17th century (painting) and 19th century (page). Ink, opaque watercolor, and gold on paper; $29.5 \times 19 \mathrm{~cm}$. Walters Art Museum, Baltimore, W.668, fol. 29a

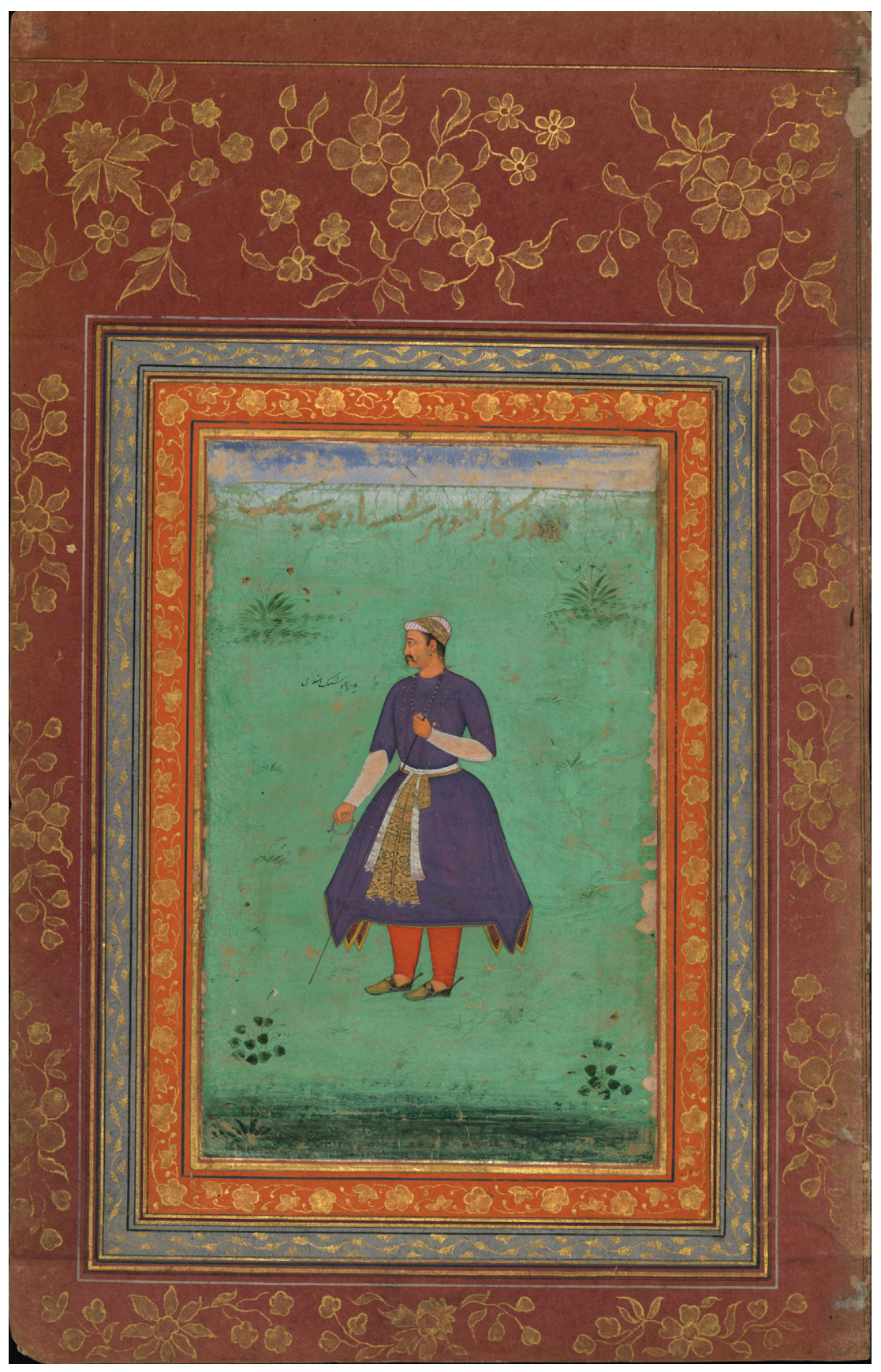

enterprise (fig. 17). To be proficient as an artist, one had to sit, carry the brush, and position paper supports in specifically circumscribed ways.

The painters active in the Mughal manuscript workshop often exercised their skills by transferring freehand or by means of a tracing or pounce a pre-existing tarh from one surface (often but not always paper) to another. These acts of duplication were, again, part and parcel of the ways in which premodern South Asian painters demonstrated their knowledge and mastery of a corpus of images and a chain of makers; they were also fundamental to how artists learned and inhabited their profession. The duplication of compositions incorporated 


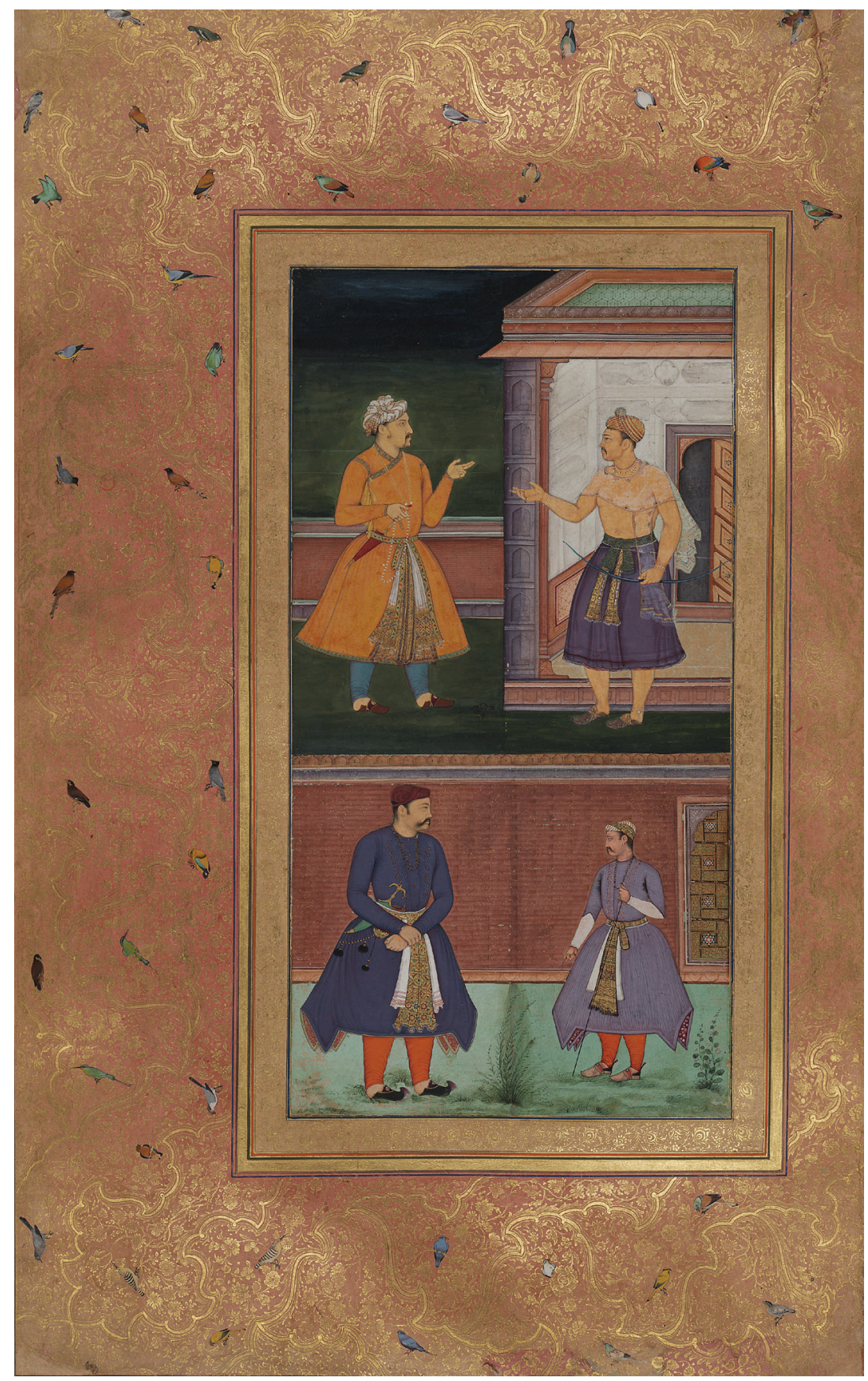

FIGURE 14. Page from the Gulshan Album bearing four portraits, northern India, ca.

1599-1618 (page). Ink, opaque watercolor, and gold on paper; $42.2 \times 26.5 \mathrm{~cm}$. Staatsbibliothek zu Berlin, Libri picturati A 117, fol. 18v

a diverse range of technical expertise, including, but not limited to, tracing, pouncing or pricking, and freehand drawing, all of which necessitated finely tuned hand-eye coordination. These exercises did not serve reproductive goals alone, for copying practices played an important pedagogical function by guiding junior artists through the physical, iterative motions required to produce the lines of the designs on the page. In this sense, the Mughal painter's knowledge was incarnate. Through the artist's repeated copying of stock gestures and compositions (which were themselves often copies), skill was at once generated by and sedimented in the body. ${ }^{16}$ 


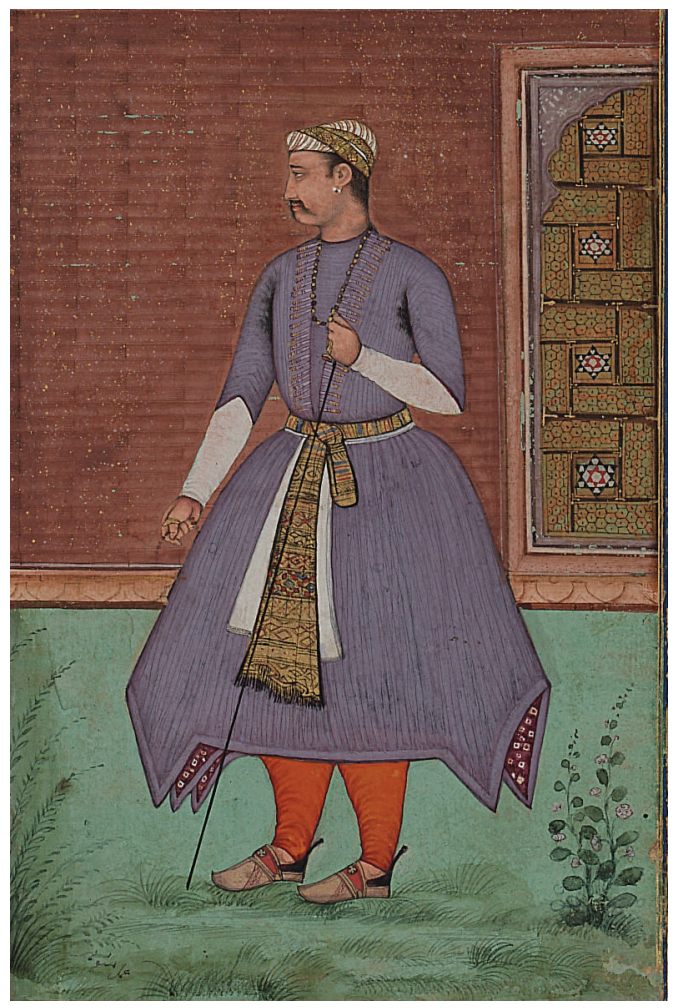

The seventeenth-century Mughal manuscript workshop was by no means a hermetic institution: the staff of painters in the atelier fluctuated dramatically over time, and discrete drawings and tracings, manuscripts, and albums circulated as gifts and booty, as well as in the company of itinerant artists themselves. The political turmoil that plagued the Mughal capital during the first part of the eighteenth century also saw the massive translocation of royal painters and paintings from Delhi to the regions of Awadh, Bengal, and the Deccan, where new and moneyed patrons could be found in larger numbers. ${ }^{17}$ Indeed, many of the painters employed in these others workshops had been trained in Mughal ateliers, were themselves descended from Mughal artists, or had access to imperial Mughal paintings and drawings. In some cases, all three factors came into play.

What, then, drove eighteenth-century artists in these locations to reproduce seventeenthcentury Mughal compositions? The desire to claim mastery of a corpus of earlier established compositions, and thus membership in a storied chain of earlier artists, was likely a motivating factor. Artists' and patrons' aspirations to incorporate, literally and symbolically, the traces of Mughal sovereignty in the shape of imperial portraits and other designs also comprised a significant rationale underlying the far-reaching reproduction of forms. In the Awadhi city of Lucknow, where the St. Cecilia painting now in Jaipur likely was produced, the Mughal arts of the previous century remained a lasting touchstone, not least because of the political, cultural, and intellectual ties that the nawabs and others (including Europeans) in the region maintained with the Mughal court in Delhi. In many ways, it was the sustained engagement of eighteenth-century artists in these locales with these earlier materials, and specifically through acts of copying, that contributed to the continued canonization and valorization of seventeenth-century Mughal painting well into the nineteenth century and after. 


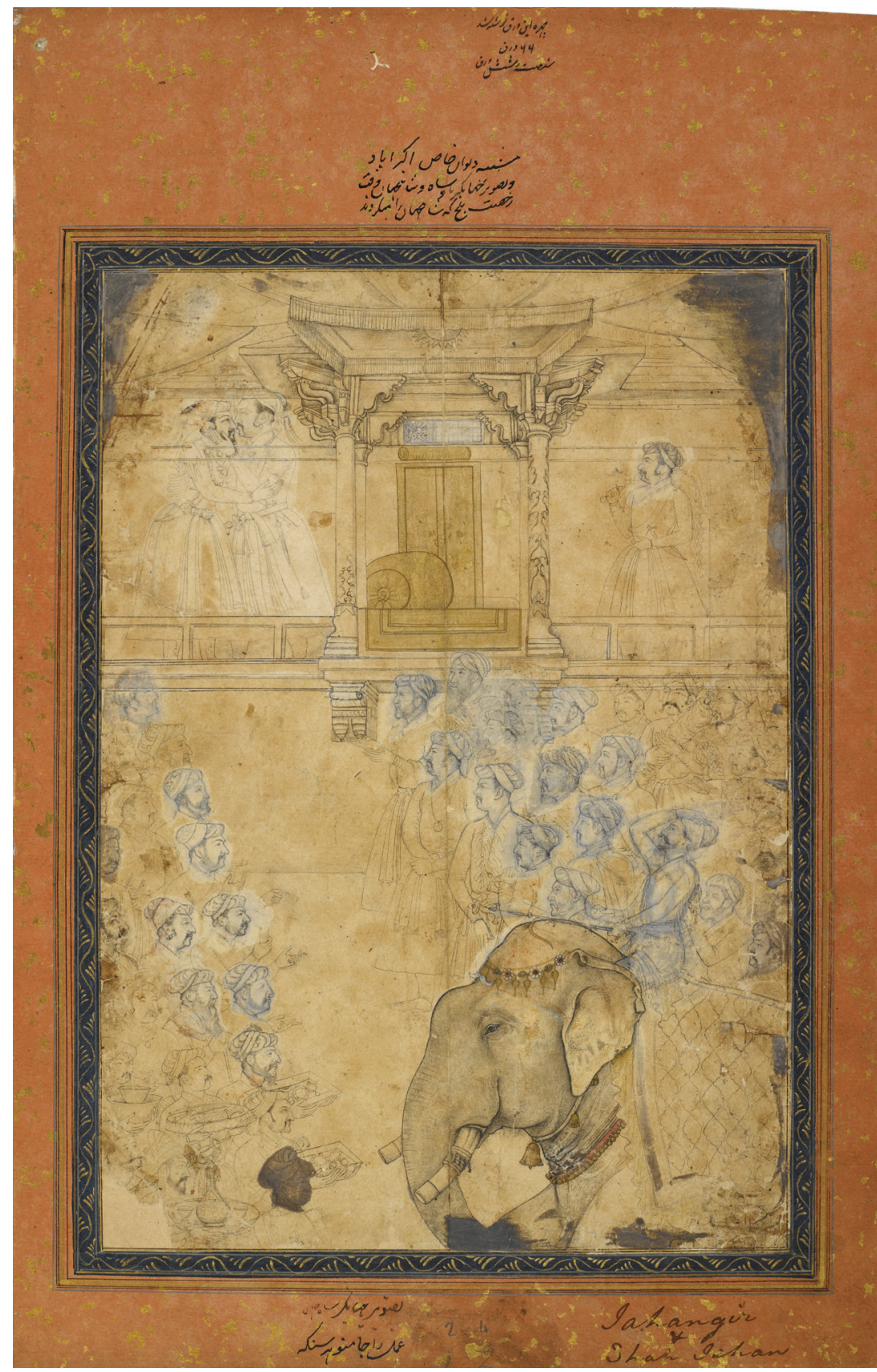

FIGURE 16. Preparatory drawing (tarh) depicting Jahangir embracing Prince Khurram (the future Shah Jahan) upon his return from the Deccan in 1617, northern India or the Deccan, ca. 1635-40. Ink and opaque watercolor on paper, drawing: $29.6 \times 20.8 \mathrm{~cm}$; page: $41.1 \times 26.6 \mathrm{~cm}$. British Library, London, Johnson Album 4, 2. (c) British Library Board

For the Kachhwaha rulers of Jaipur and their painters, the copying of Mughal designs provided a potent means to forge affiliations with their political and artistic antecedents. Of course, these associations were grounded in the intertwined histories of the two dynasties: the Kachhwaha Rajputs, after all, had enjoyed marital and political ties with the Mughal family since 1562, when Raja Bharmal married his daughter (the aforementioned Jodha Bai) to Emperor Akbar in order to establish ties with the Mughal sovereign. While the Kachhwahas' collection of works (such as the St. Cecilia in Jaipur) afforded these rulers material links to this imbricated past, it was in their artists' reproduction of Mughal designs that these connections were (and are) most keenly and physically felt. As demonstrated by yet another iteration 


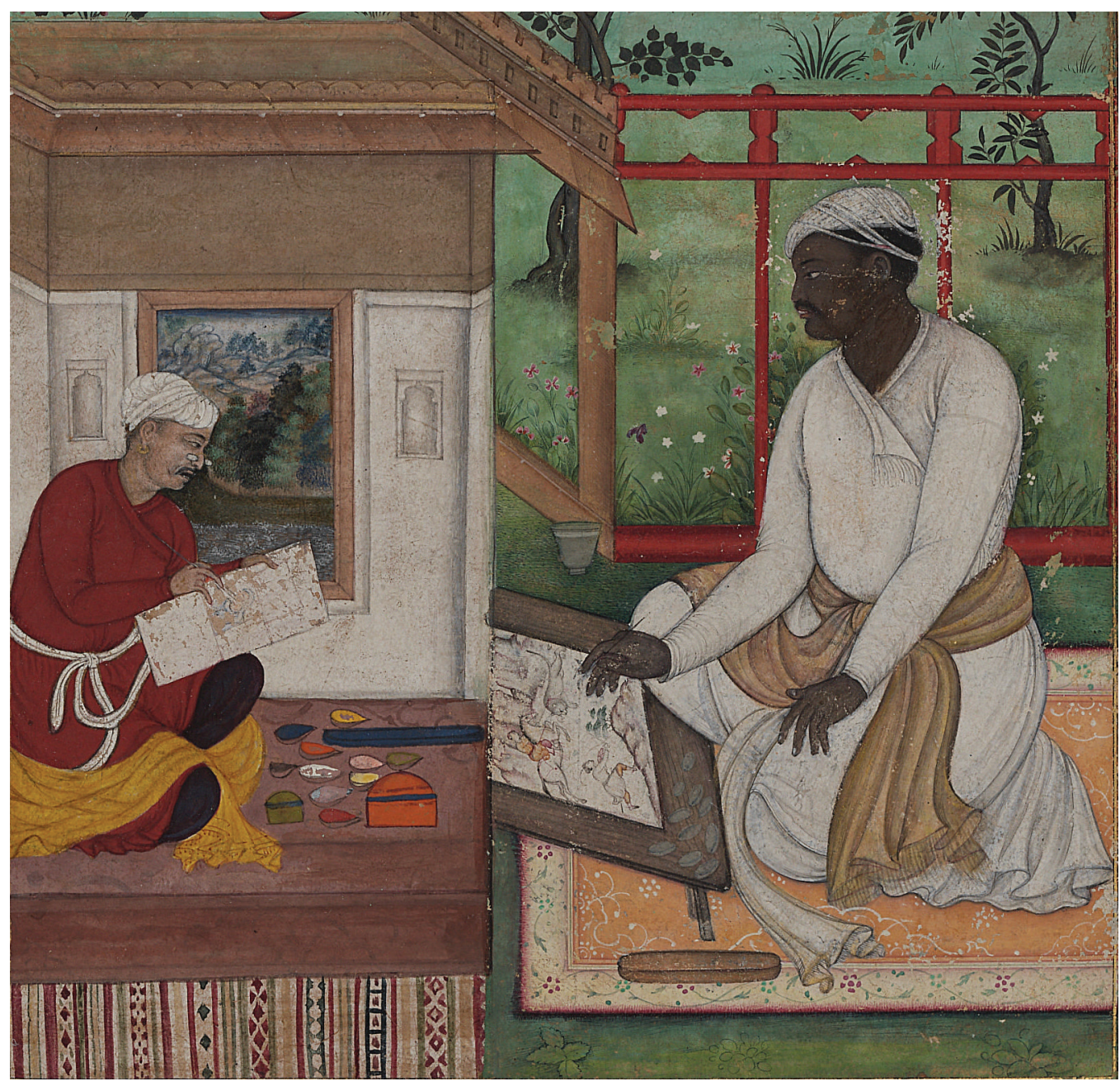

FIGURE 17. Paintings showing painters at work (detail) mounted on a page from the Gulshan Album, northern India, late 16th-early 17th century (paintings) and ca. 1599-1618 (page). Ink, opaque watercolor, and gold on paper; detail: $13.5 \times 12.1 \mathrm{~cm}$; page: approx. $42.2 \times 26.5 \mathrm{~cm}$. Staatsbibliothek zu Berlin, Libri picturati A 117, fol. $21 \mathrm{r}$

of the now-familiar mallard, produced in the royal Kachhwaha workshop around the turn of the nineteenth century, the Jaipur act of copying centered in large part on the technical and corporeal process of reproducing a set arrangement of lines (fig. 18). The work's relationship to the mallard paintings introduced previously lies in the continuity of the duck's contoured design across all four compositions (see figs. 7-9, 18). These examples reveal how artists' acts of copying were concentrated in discrete, outlined forms, which could be rearranged and recontextualized as desired; to copy, in this sense, was to embody a way of making grounded in delineation, hence tracing oneself into history. ${ }^{18}$

The emphasis placed by the seventeenth-century Mughal manuscript workshop on the distillation of form in the hard lines of the compositional tarh, and the latter's rootedness in rote, learned, and embodied knowledge, in short, very likely contributed significantly to the widespread reproduction of Mughal designs in manuscript workshops elsewhere in South Asia. Imminently technical and corporeal in nature, copying necessitated the emulation of very particular ways of designing and making that inhered in, and were transmitted by, bodies and objects of knowledge. 


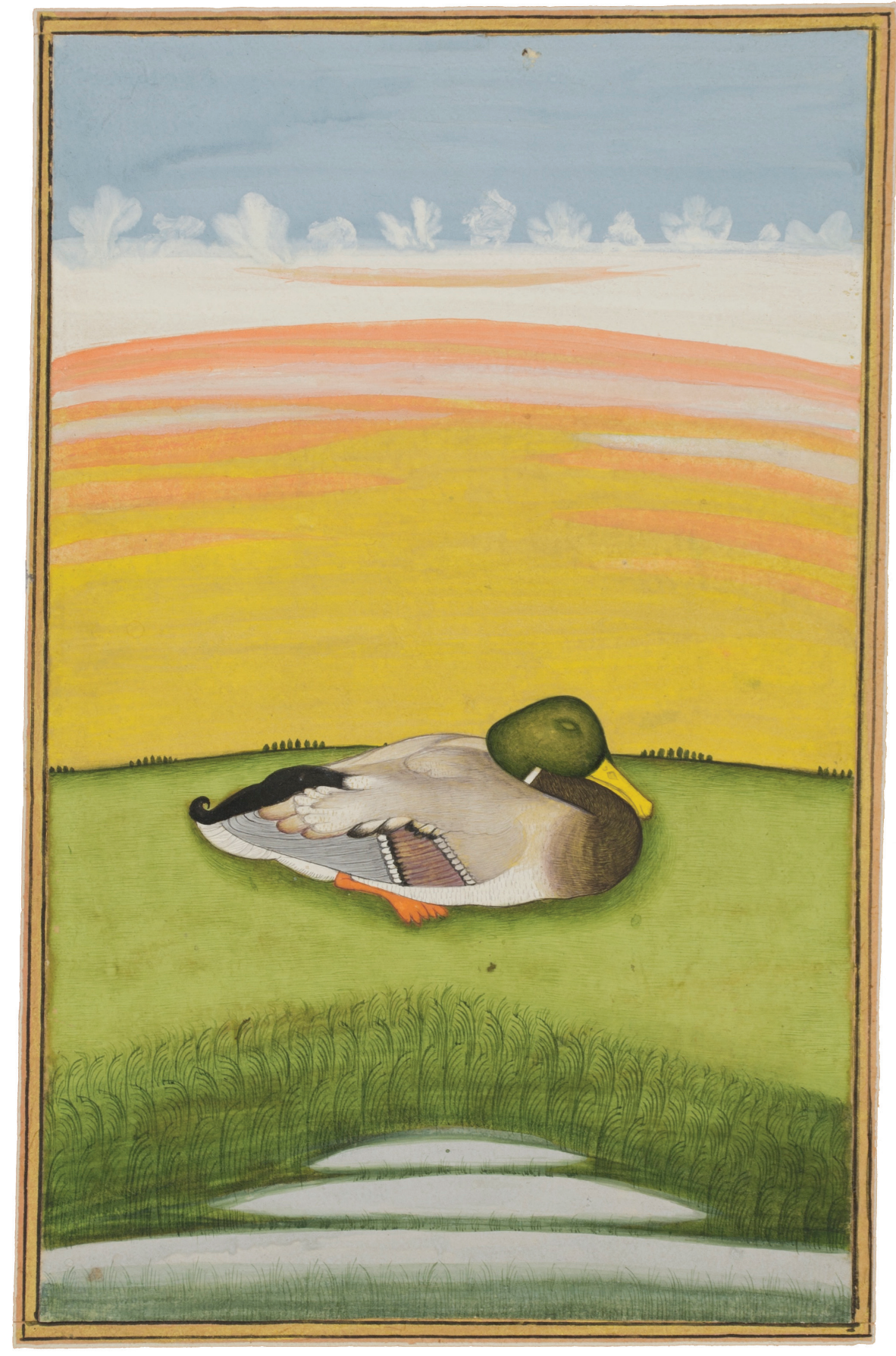

FIGURE 18. Page from an album bearing a painting of a sleeping mallard, Jaipur, early 19th century. Opaque watercolor on paper. Maharaja Sawai Man Singh II Museum, Jaipur, AG 1298. (C) Maharaja Sawai Man Singh II Museum Trust

\section{Compilation and Circulation: The Album as a Technology of Reproduction}

Many of the paintings addressed thus far in this essay circulated across and beyond South Asia not as standalone works but as components of larger album (or muraqqa') ensembles. This point is hardly incidental: as a highly mobile and contingent type of book technology, the album arguably played a fundamental role in propelling the circulation and reiteration of seventeenth-century Mughal compositions. The muraqqa' functioned, on the one hand, as an organizational and framing device, and, on the other, as an agent for the circulation and reproduction of images. 
FIGURE 19. Page

from an album

bearing a portrait

of Humayun

(r. 1530-40,

1555-56),

northern India,

ca. 1630s-early

1650s (painting)

and early

1650s (page).

Ink, opaque

watercolor, and

gold on paper;

painting: $22 x$

$14.3 \mathrm{~cm}$; page:

$38.1 \times 22.2 \mathrm{~cm}$.

Bodleian Library,

Oxford University,

Ms. Douce Or.

a. 1 , fol. $21 \mathrm{r}$

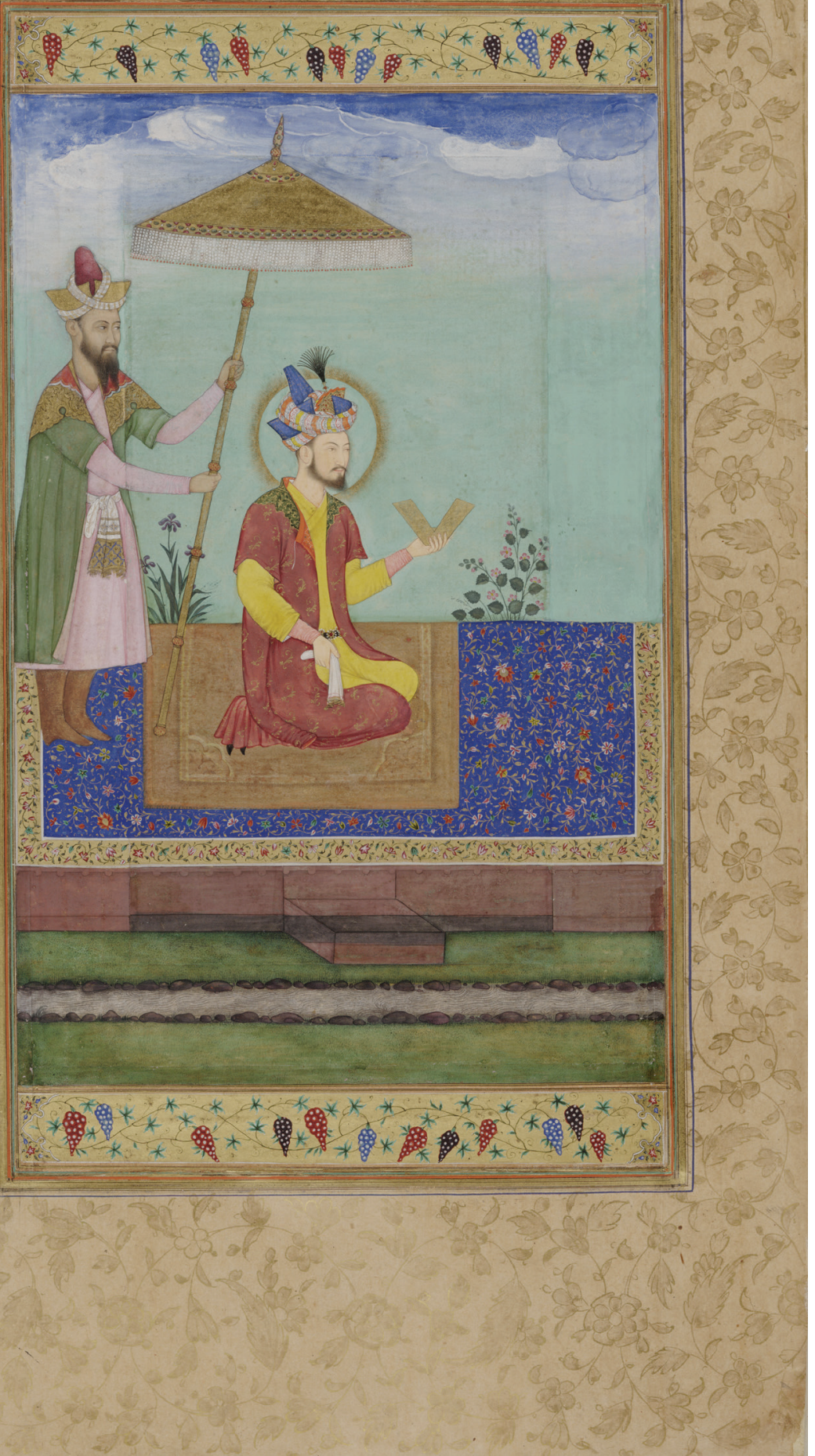




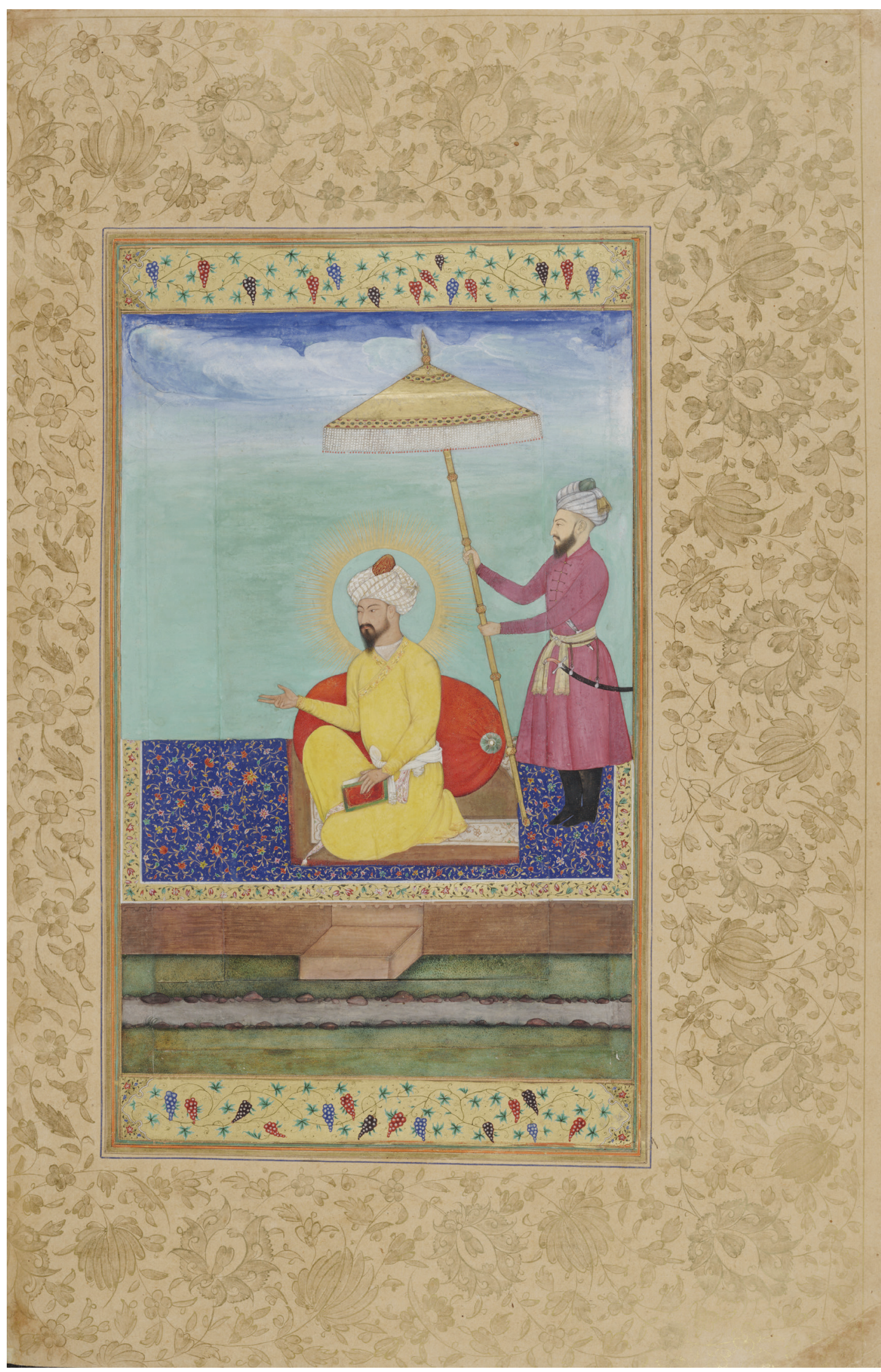

FIGURE 20. Page

from an album

bearing a portrait

of (possibly) Babur (r. 1526-30),

northern India, ca.

1630s-early 1650 s

(painting) and early 1650s (page). Ink, opaque watercolor and gold on paper; painting: $21.5 \mathrm{x}$ $14.5 \mathrm{~cm}$; page: $38.1 \times 22.2 \mathrm{~cm}$.

Bodleian Library, Oxford University, Ms. Douce Or. a. 1 , fol. $20 \mathrm{v}$ 
Let us return to the St. Cecilia images in London and Jaipur, as both very clearly were prepared for use in muraqqa's (see figs. 1 and 3). To appreciate this point most fully, we must zoom out and away from the paintings to view them once again as discrete illustrated units that were mounted, or collaged, with fragments of calligraphic Persian poetry on a durable paper support. Both bear a series of framing devices composed of decorated borders and margins, which focus the viewer's eye on the paintings that sit in the centers of the pages. Yet, these elements pull our gaze at the same time to the paintings' perimeters, where blooming flowers, poetic verses, and (in the case of the Jaipur page) birds compete for our attention. It is important to understand, however, that although we view these works today as standalone units, they once would have comprised one half (in both cases, the left-hand side) of an album's double-page spread. This album-book context would have functioned as an additional framing apparatus by presenting the two recto pages and their now-absent verso pages as a single field unified by their shared organizational schema and the central gutter margin. Hence, both the London and Jaipur images originally would have been intended to be apprehended not as single, discrete leaves, but as components of larger visual fields.

The binary configuration of the muraqqa', exemplified by its two-page openings and alternating text-and-image arrangement, interchanging page spreads containing calligraphies with page spreads containing pictorial images, encouraged viewers to perceive the codex's contents as a series of intentionally paired juxtapositions. The fighting camels ascribed to Bihzad and Nanha, discussed earlier, are but two works from the Gulshan Album that were mounted on facing verso and recto pages to facilitate this kind of comparative analysis (see fig. 6). Each of the artists' paintings was rotated ninety degrees to accommodate it to the album's vertical format, meaning that, upon first glance, the album's user apprehended the compositions firstly as formal abstractions and only secondly, upon turning the codex to view the fighting camels and their accompanying Persian annotations right-side up, as identifiable subject matter. This arrangement invited the viewer to compare the paintings in terms of line, color, and overall design, and then to take in the two works as variations upon a single iconographic theme. The album's juxtapositions nevertheless imply an underlying hierarchy: it is no coincidence that the painting ascribed to Bihzad precedes Nanha's work. (Recall, after all, that Persian-language books typically are read or viewed from right to left.) In this way, the Gulshan Album's pairing of the wrestling camels makes the case for the membership of the Mughal artist in a longer artistic lineage that linked him to the legendary Bihzad.

Utilizing the format of the codex in these ways, the album persuaded its users to make connections among artists who had lived at different times. In a similar vein, album makers used the codex's two-page spread to advance patrons' claims of succession and affiliation as well. Take, for example, the facing pages from another Mughal album, this one likely created for a member of the royal family sometime during the 1650s (figs. 19, 20). The verso page, also the right-hand side of the pair, bears a portrait of a figure who likely represents Babur (1483-1530, r. 1526-30), the founder of the Mughal dynasty, while the facing recto page, or left-hand side, shows a depiction of Babur's son and heir to the throne, Humayun (1508-1556, r. 1530-40, 1555-56). The order of succession is indicated by the placement of the father on the page preceding the portrait of the son. Yet, the choice to relegate each sovereign to his own page, rather than portray the father and son together within a single continuous visual field, also has the effect of underscoring the temporal and regnal distinctions between the two. Humayun, after all, post-deceased Babur by twenty-six years, and his reign was beset by tribulations unique to his own time. Thus, in mounting the two rulers on opposite pages, the 
album's makers emphasized these important generational differences at the same time that they suggested that the binary format of the muraqqa' is what allows Babur and Humayun to commune once again. It is surely no coincidence that each sovereign is portrayed as if facing the other, the book's gutter margin being the glue that binds them.

The album codex's binary configuration made meaningful juxtapositions like these possible, and the capacity of these books to express such consequential associations perhaps even contributed to the uptick in their production at the Mughal court during the seventeenth century. During Shah Jahan's tenure as padshah ("master king," or emperor), in particular, the Mughal production of albums and album paintings expanded in volume, if the very large mass of extant mid-seventeenth-century materials of this kind is any indication. No longer the purview of the emperors alone, albums increasingly were patronized, circulated, and recirculated once again by royals and elites seeking to cement social ties and establish their membership in courtly, cosmopolitan circles. The seventy-four folios of paintings, prints, and calligraphies collected in the Dara Shikoh Album, which the eponymous prince and imperial heir (1615-1659) had assembled during the 1630s, possibly as a future gift for his wife, Nadira Banu Begam (1618-1659), is testimony to the efflorescence of the medium as an object of exchange. ${ }^{19}$ This album, now in the British Library, is unusual as one of only a few seventeenth-century examples that preserve their original arrangement (more or less); princes and other elites commissioned many other albums that subsequently were dismantled, their parts later incorporated into newly conceived and patched compilations. ${ }^{20}$

Along with the explosion of Mughal album materials over the course of the seventeenth century, the types of images mounted in these books came to be limited increasingly to an established repertoire that included imperial and sub-imperial side-profile portraits, genre scenes focused on royal and spiritual figures, occupational and courtly types, animal and floral studies, and collected pictorial specimens associated with earlier eras, in particular the reign of Jahangir. In other words, the flourishing production of albums was paralleled by the increasing canonization (and, as we have seen already, copying) of their contents, a process that would continue into the eighteenth century as well.

The increased salience and production of Mughal albums did not necessarily guarantee, however, that they would remain unchanged or even intact. Typical alterations included but were not limited to the addition and deletion of whole leaves and fragments of calligraphies and images, the select repainting of the album's pictorial contents, and the inscription of ownership statements and seal impressions. Numerous seventeenth-century Mughal albums exist today in fragmentary states, with their contents surviving as standalone folios or as components of albums that were assembled only in the eighteenth and nineteenth centuries. The St. Cecilia images in London and Jaipur are but two such examples. As mentioned previously, the former is one of thirty-three album folios that the Victoria and Albert Museum acquired in 1921, a group comprised of a motley mix of leaves that were assembled between the seventeenth and nineteenth centuries. That is to say, the muraqqa' for which this St. Cecilia page was prepared no longer survives in its original state. The Jaipur painting similarly endures as a discrete leaf bereft of a codex.

Multiple factors contributed to the album's vicissitudes. Some albums were tied so evidently to their patrons-through seals, portraiture, poetry, or other means-that subsequent owners often materially amended them to make them more clearly theirs. Such was the case with the Gulshan Album, which Shah Jahan apparently altered with minor additions after inheriting it from Jahangir, the book's original patron. Conflict later catapulted the Gulshan Album (along 
with a number of other Mughal albums) to Iran, probably as part of the booty scored by the aforementioned Afsharid ruler Nader Shah during his looting of the Mughal treasury in Delhi in 1739. There the Afsharid owners of these albums, and their manuscript specialists, modified them yet again to make these works express their own aesthetic preferences and political claims. The material contingencies of muraqqa's-their construction from unnested bifolios composed of thick, layered leaves; the use of glues and many units of paper to construct the tableau of each page; the flaking of paint and the evidence of smudges-further begged for physical intervention. Indeed, it could be said that albums, being so modular and hence easy to take apart, even invited their own dispersal.

The contents of Mughal albums played no small part in propelling these composite books into global orbit. Their preponderance of calligraphed qit'as (short poems), standardized (and thus familiar) royal portraiture, and pictures employing European (known in Persian as firangi) subject matter and artistic styles ensured the broad resonance of the muraqqa' across multiple cultural and linguistic registers. For the seventeenth-century Mughal patrons of these albums, this program of texts and images expressed the cosmopolitan and sometimes cosmological ambitions of the sovereigns and their associates. Among the most famous such examples are the early so-called allegorical paintings of Jahangir, which depict the Mughal emperor defeating his enemies, among other activities, while standing on a European terrestrial globe. ${ }^{21}$ These works, which were mounted in the St. Petersburg Album, a muraqqa' (since dispersed) assembled in Iran in the mid-eighteenth century, likely once formed part of one of the Mughal albums that Nader Shah may have acquired during his invasion of Delhi. ${ }^{22}$

For eighteenth- and nineteenth-century Awadhi, Bengali, Rajasthani, and Deccani elites, the collection, patronage, and copying of muraqqa's and their contents offered, in part, the concrete means to espouse cultural, political, and genealogical affiliations with the Mughal padshahs of the seventeenth century, with whom albums were indelibly associated by that point. ${ }^{23} \mathrm{As}$ in the seventeenth century, the production, circulation, and presentation of albums and album contents continued to serve as a means for elites to identify themselves as constituent members of a cosmopolitan network of exchange, and hence to accrue political and social capital. The associations that the patrons of Persianate muraqqa's shared with Mughal sovereignty also spurred the persistent assemblage and patronage of albums as well as the copying and collection of Mughal pictorial compositions to mount in them. The political fragmentation of the Mughal Empire over the course of the eighteenth century-concomitant with the rise of the nawabs of Awadh and Bengal, the British and French East India Companies, and the Maratha Empire (1674-1818) and other princely states-led to the dynasty's precipitous loss of imperial power, to the extent that, by the end of the 1750s, the Mughal emperor 'Alamgir II (1699-1759, r. 1754-59) operated as little more than a titular head. The invasions of Delhi in 1739 and 1788 by Nader Shah and Ghulam Qadir Shah (d. 1789) of the Afghan Rohillas, respectively, are but two of the many assaults made upon the Mughal capital during this time. Yet in spite of these losses, the Mughal court retained its authoritative (if also largely symbolic) potency, and the South Asian, Central Asian, and European entities who had filled the power vacuum capitalized on this fact by commissioning architectural monuments and cultural artifacts, including albums, that articulated their real and imagined proximity to the legendary Mughal sovereigns. ${ }^{24}$ Artists employed in the late Mughal manuscript workshop in Delhi also drew upon and sometimes even copied seventeenth-century Mughal albums and album pages to make their own claims to the dynasty's earlier, storied patrons and histories. 
It was during this period that the pool of patrons, collectors, and purveyors of South Asian albums expanded to include European colonial elites like Antoine-Louis-Henri Polier (1741-1795), a Swiss engineer who worked for both the French and British East India Companies before finally finding employ at the Lucknow court of Shuja' al-Dawla (1732-1775), nawab of Awadh. ${ }^{25}$ While Polier famously commissioned a large number of new paintings from artists working in Lucknow for compilation in albums, he also collected works that had been created some years prior at the Mughal and Awadhi courts. ${ }^{26}$ Much of Polier's collection of albums later would be dispersed following his return to Europe in 1788. It was through Polier, as well as a host of other highly mobile and politically powerful figures (as well as collectors), such as the East India Company agents Elijah Impey (1732-1809), Richard Johnson (1753-1807), and Gore Ouseley (1770-1844), that many South Asian albums and discrete album pages made their way via auction sale to new collectors in London and other European centers during the nineteenth century, and thence to North America beginning about a century later. ${ }^{27}$

Many albums and album materials nevertheless continued to circulate in South Asia, where royals and elites remained their most enthusiastic consumers. According to an akhbar (news report) penned in Delhi in 1819, the nawabs of Awadh were among those who purchased albums and album paintings formerly in the collection of Claude Martin (1735-1800), a major general in the East India Company who had resided in Lucknow from 1776, following his death. ${ }^{28}$ Shuja' al-Dawla, meanwhile, commissioned an album comprised largely of seventeenth-century Mughal portraits and calligraphic samples, which, having been inherited by the patron's successor, Asaf al-Dawla (1748-1797), found its way (perhaps in the form of a gift) into the hands of the English king George III (1738-1820, r. 1760-1820) in the early nineteenth century. ${ }^{29}$ Awadh and Delhi in the eighteenth and early nineteenth centuries also remained major centers for the production of copies of seventeenth-century Mughal paintings, which circulated, along with works of demonstrably seventeenth-century provenance, in series or collections assembled in the form of albums. Some of these, like the Morgan Library's Read Mughal Album, the Victoria and Albert Museum's Wantage Album, and the Metropolitan Museum of Art's Shah Jahan Album, would be redistributed to European and North American collections over the course of the nineteenth century. ${ }^{30}$ Others, however, found second (or third and fourth) homes in royal centers like Jaipur, where artists recontextualized these materials yet again as components of new albums and as models for copying.

Indeed, during the eighteenth and nineteenth centuries, the Kachhwaha maharajas of Jaipur came into the possession of a number of albums and album paintings associated with the Mughal and Awadhi courts, which their artists, in turn, further recombined in new album arrangements. In her pioneering study of the Jaipur suratkhana (painting workshop), Shailka Mishra explains that "Mughal-style [muraqqa's] were among the earliest purchases made by the suratkhana." ${ }^{17}$ She also provides important textual evidence indicating that the suratkhana's employees even assembled their own Mughal-style albums from purchased materials and works created on-site, many of the latter being images made to emulate the painting styles of the Mughal, Awadhi, and Rajasthani courts. These activities apparently began in earnest during the 1740s, coinciding with the reign of Maharaja Ishwari Singh (1721-1750, r. 1743-50). His brother and successor, Madho Singh I (1728-1768, r. 1750-68), continued this trend, often utilizing the royal suratkhana's muraqqa's as diplomatic gifts. In these ways, Mughal and other related albums and album contents were recirculated and reconceived once again.

The St. Cecilia image in Jaipur was likely among the materials that the Kachhwaha suratkhana acquired, possibly by purchase, during the eighteenth century (see fig. 3). The very 
existence of this album page (recall, too, the similarity between its dimensions and those of the St. Cecilia image in London) allows us to trace the provenance of some items in the Maharaja of Jaipur's collection directly to Awadh. This is hardly a revelation, as many other materials in the Jaipur collections draw from albums that must have been assembled in Awadh, not to mention at the Mughal court and royal centers in the Deccan during the seventeenth and eighteenth centuries..$^{32}$ Just why the Jaipur image was left as a single, standalone folio rather than compiled into a muraqqa is suggested by an inscription in Devanagari script located in its lower border. Reading pano buri, meaning "bad (or damaged) leaf," the epigraph is a judgment of the fitness of the album folio for future use. ${ }^{33}$ Whatever may have been the cause of the folio's many tears, the resulting damage-and not the painting's status as a "mere" copy of an early seventeenthcentury Mughal work-had rendered it defunct. No doubt it was precisely the object's putative association with Mughal patronage that had made it valuable to the Jaipur court in the first place. The Kachhwahas, of course, had enjoyed familial and political ties with the Mughals since the sixteenth century; during the eighteenth century, their collection of Mughal albums and album contents was a means to underscore materially and visually these long-standing connections to the Mughal dynasts, who still very much possessed an aura of authority despite major territorial and other losses.

The Jaipur suratkhana's appropriation of the Mughal muraqqa' nevertheless involved a range of adaptations, which effectively reinvented the very concept of the album. As Mishra shows, the Jaipur muraqqa' was far more expansive in scope than the Mughal muraqqa' was or had been. This version of the form encompassed collections of juxtaposed pictorial materials along the lines of what might be expected in a Mughal muraqqa'. Kachhwaha muraqqa's, however, also included what Mishra describes as "paintings traditionally associated with Rajput courts-ragamalas ["garlands of ragas," or musical modes], baramasa ["twelve months"]," and other works that combined poetry with pictorial compositions. ${ }^{34}$ The Jaipur suratkhana also eschewed the Mughal and Awadhi concern with elaborate border decoration and use of double-sided folios. ${ }^{35}$ Far from representing a corruption of the Mughal album format, the wholly unique appearance of later eighteenth-century Kachhwaha muraqqa's is testimony to the mobility, potency, porosity, and translatability of this pervasive book technology.

\section{Brokers of Dissemination: Nandaram Pandit and the Wantage Album}

The Mughal Empire's decentralization and the repeated invasions of Delhi hastened the dispersal of imperial albums and album contents to alternative hubs of influence in Lucknow, Faizabad, Murshidabad, Hyderabad, and Jaipur, thereby ensuring that the new communities of album collectors and patrons of the eighteenth and early nineteenth centuries had access to these kinds of materials. Natalia Di Pietrantonio recently has shown that a range of South Asian local actors subsequently trafficked in some of these dispersed materials, their express goal being to restore these works to royal collections and thus save them from "further degradation in the open market." ${ }^{\prime 6}$ The looting of the Mughal library by Nader Shah and Ghulam Qadir

Shah, in other words, may be understood as but two episodes (albeit quite sudden and farreaching events) in the ongoing redistribution of albums and album contents to alternative centers of authority by well-connected powerbrokers.

The transmission westward of the St. Cecilia image in London likely was owed to the agency of one such individual, although this possibility has long been obscured by scholars' misapprehension of this person's identity and the larger context of the so-called Wantage Album, of which that particular page is a part. ${ }^{37}$ When the Wantage Album's thirty-three leaves entered 


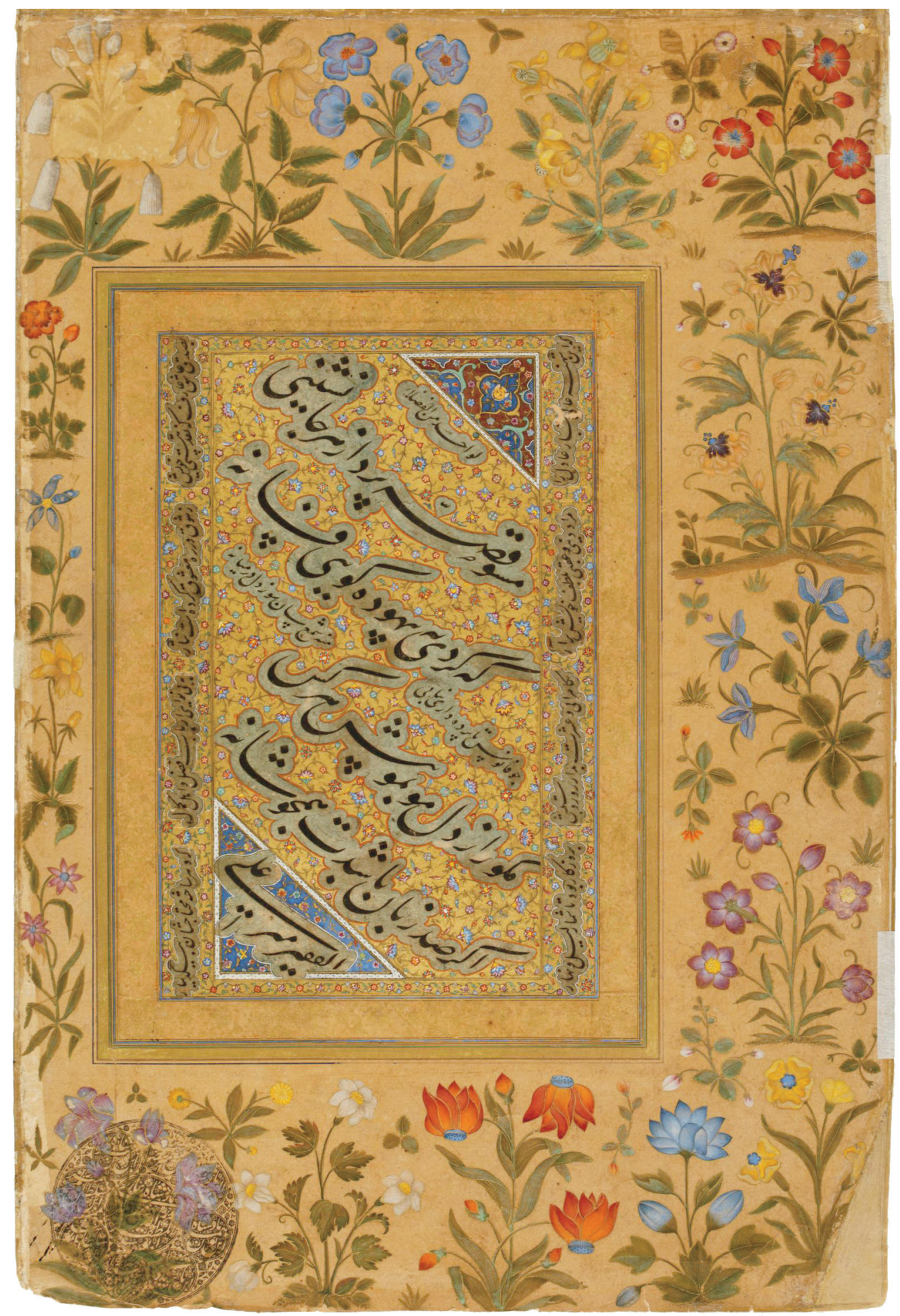

FIGURE 21. Page from the Wantage Album bearing a calligraphic specimen signed by Mir 'Ali (ca. 1509-1549) and Jahangir's imperial seal, northern India, 17th century (illumination) and 1630s (page). Ink, opaque watercolor, and gold on paper; page: $38.3 \times 25.8 \mathrm{~cm}$. Victoria and Albert Museum, London, IM.139A-1921 
the Victoria and Albert Museum's collections in 1921, it was believed that the thirty-five paintings included among the folios had been made at the courts of the Mughal emperors Jahangir and Shah Jahan; indeed, many of the reverse sides of these folios, including the verso of the page with the St. Cecilia image, bear impressions of Jahangir's imperial seal with the date of AH 1020 (1611-12; fig. 21). ${ }^{38}$ Slightly more than two decades later, Moti Chandra established that a number of the paintings from this group in fact had been created in India around the turn of the nineteenth century. ${ }^{39}$ Rosemary Crill and Stuart Cary Welch later would argue that the Jahangir-era imperial seal impressions were added to the Wantage Album pages only in the early nineteenth century; the appearance of the seal of Nandaram Pandit on twenty of the album's pages, including on folios that also bear the Mughal imperial seal, gave a name to the mastermind of this enterprise (fig. 22). ${ }^{40}$ Crill concluded that Nandaram Pandit must have commissioned a number of "fake paintings," which he then stamped with Jahangir's seal and combined with "genuine" (i.e., seventeenth-century Mughal) paintings to sell to "the gullible British, who recognized the imperial seal even if they were less discriminating about the standards of the paintings." 41

The problem with this theory is that it not only neglects to account for the longer and ongoing history of South Asian artists producing "authentic" copies of earlier, canonical compositions for compilation in albums, not to mention the copious documentation attesting to the integral and presumably well-informed involvement of British colonial agents as collectors and patrons of Indian painting, but the evidence provided by the seal impressions in the album does not even support the argument. In fact, of the eighteen Wantage Album folios stamped with Jahangir's imperial seal, fourteen folios bear Mughal paintings dating to the seventeenth century, with the lion's share being works associated with Jahangir's patronage. ${ }^{42}$ The fifteen folios that lack Jahangir's imperial seal include eighteen paintings that date from the late eighteenth and early nineteenth centuries. It also should be noted that all of Jahangir's imperial seal impressions are found on the sides of folios bearing calligraphic specimens. Following Crill's argument, it is precisely the pages mounted with eighteenth- and nineteenth-century

FIGURE 22. Detail of the Nandaram Pandit seal impression on a page from the Wantage Album, northern India, 18th century (seal impression) and 17 th century (page). Ink and gold on paper. Victoria and Albert Museum, London, IM.137-1921

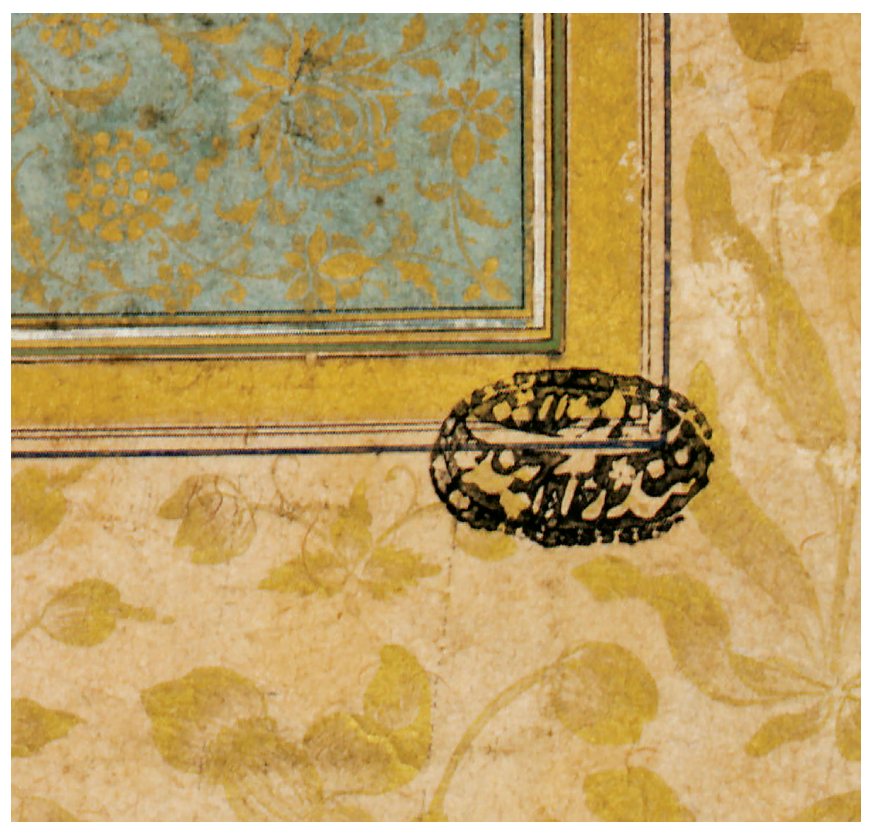


paintings that should have been stamped with the early seventeenth-century Mughal imperial seal if the real intention was to hoodwink "gullible British" into believing that they were acquiring "genuine" works completed centuries prior. Still to be reconciled, however, is the appearance of Jahangir's imperial seal on borders in the Wantage Album that post-date both the recorded date of 1611-12 and the emperor's reign. ${ }^{43}$ If the seal impressions were not added as part of a campaign to manufacture fakes for dupable Europeans, how can their existence otherwise be explained?

To attempt to elucidate this phenomenon, we must return to the figure of Nandaram Pandit, whom art historians have long judged to have been an unscrupulous early nineteenthcentury dealer. ${ }^{44}$ This Nandaram Pandit, however, may very well be the figure of the same name who served as clerk to Hyder Beg Khan, a powerful minister to the aforementioned Asaf al-Dawla, the nawab of Awadh, from 1775 to 1797. A letter dated 24 Shawwal AH 1200 (August 20, 1786), written by Claude Martin to "Raja Nand Ram Pandit" regarding a loan that the Frenchman made to, or that perhaps was negotiated by, Hyder Beg Khan, establishes the clerk's presence in Lucknow during the last quarter of the eighteenth century. ${ }^{45}$ Some years earlier, however, Nandaram Pandit seems to have situated himself as a power player in Awadh, moving easily between the courts of the nawabs and their ministers and European circles. He apparently developed a close enough relationship with Richard Johnson-who served as Assistant to Nathaniel Middleton (1750-1807), the Resident of Lucknow, from 1780 to 1782 and then as Resident of Hyderabad from 1784 to 1785-to have copied for him a Persian translation of Euclid's Elements (Tarjama-yi Tahrir-i Uklidis) bearing a completion date of 1 Rajab AH 1194 (July 3, 1780). ${ }^{46}$ It was Johnson's collection of illustrated and unillustrated manuscripts and single-leaf paintings from India that was among the first purchased by the East India Company's library in 1807, and that today forms the bulk of the British Library's collection of South Asian manuscript paintings.

Far from being a dealer, then, Nandaram Pandit seems actually to have been a member of the Brahmin secretarial class in Awadh, and in that capacity, he worked closely with the nawab's minister and such key East India Company figures as Martin and Johnson, both of whom were also serious patrons and collectors of South Asian art. It is relatively easy now to imagine how Nandaram Pandit might have come into possession or custodianship of the Wantage Album pages that bear his seal impressions. ${ }^{47}$ That he may even have been responsible for the addition of Jahangir's imperial seal to select pages of the album is suggested by the fact that it is those same pages that also bear Nandaram Pandit's seal. ${ }^{48}$ Again, whether this act was intended to deceive gullible British collectors is belied by the appearance of the imperial seal impression on folios bearing demonstrably seventeenth-century Mughal paintings, some indeed dating to Jahangir's reign. As "highly unorthodox" as the use of Jahangir's seal is in these instances, we might entertain the possibility that the multiple episodes of looting suffered by the treasury during the eighteenth century may have led to the dispersal of imperial seals to regional power centers like Awadh, where such potent marks of authority may have been put to other uses, such as to authenticate manuscript materials previously owned by or associated with members of the Mughal dynasty. ${ }^{49}$

Precisely how the Wantage Album pages came into British hands is unknown, but given the intercultural nature of patronizing and collecting art in eighteenth- and early nineteenthcentury northern India, it seems more likely than not that these folios were part and parcel of the exchange of gifts, participation in imperial collecting, and display of largesse that underlay diplomatic relations among Europeans and South Asians in the region during this period. It is 


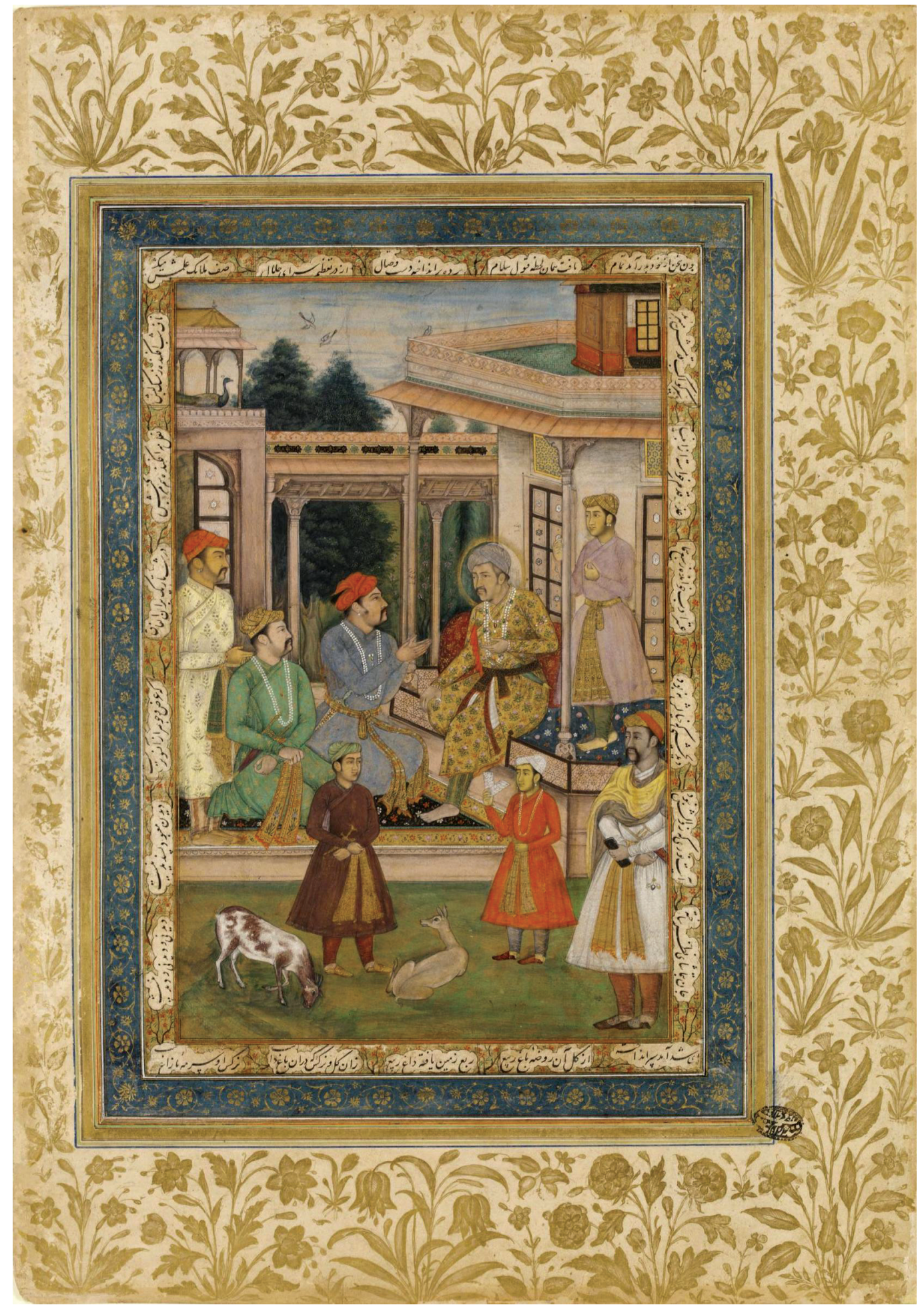

FIGURE 23. Page from the Wantage Album bearing the Nandaram Pandit seal impression and a painting of Emperor Akbar with Jahangir and Daniyal, northern India, 18th century (seal impression, page, and painting). Ink, opaque watercolor, and gold on paper; page: 38.3 × $25.8 \mathrm{~cm}$. Victoria and Albert Museum, London, IM.110-1921 


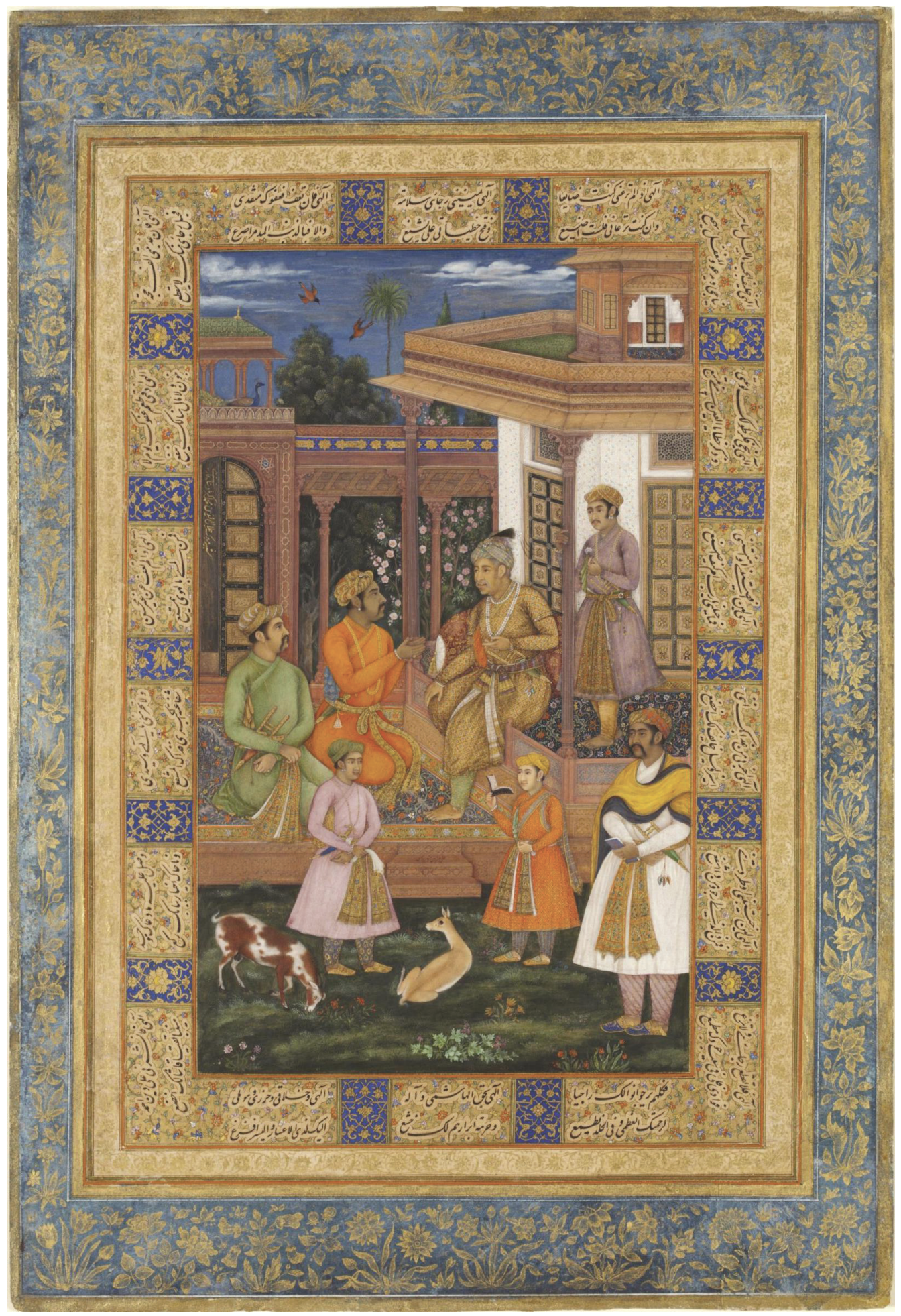

FIGURE 24. Page from the Wantage Album bearing a painting of Emperor Akbar with Jahangir and Daniyal, Delhi, 19th century. Ink, opaque watercolor, and gold on paper; page: $38.3 \times 25.8 \mathrm{~cm}$. Victoria and Albert Museum, London, IM.109-1921 
telling that among the Wantage Album's thirty-five paintings, two-both depicting Emperor Akbar receiving his sons Jahangir and Daniyal-are duplicates of each other, only one of which bears Nandaram Pandit's seal (figs. 23, 24). The painting with the seal likely was produced in a Mughal or Awadhi workshop during the eighteenth century, whereas the other work most readily recalls manuscript paintings made by Mughal artists in the imperial capital of Delhi around the turn of the nineteenth century. ${ }^{50}$ In fact, none of the Wantage pages mounted with nineteenth-century Mughal paintings includes Nandaram Pandit's seal impression, thereby suggesting that this set of leaves might have been assembled in multiple stages in Lucknow or Delhi (or perhaps in both cities) from the collections of multiple individuals. Nandaram Pandit, in the end, may have been but one among a number of local, on-the-ground agents who facilitated the circulation and reproduction of seventeenth-century Mughal designs.

This essay has attempted to flesh out in greater detail and nuance the means and processes by which Mughal pictorial forms circulated and were reproduced between the seventeenth and early nineteenth century. The study has focused in particular on two painted versions of a composition depicting St. Cecilia, an early Christian saint of the third century. The early seventeenth-century Mughal image of St. Cecilia now in London, with which this essay opens, likely arrived in England sometime between the later eighteenth and nineteenth century, but spent the first hundred or so years of its existence in India, where it originated, of course, at the Mughal court of Emperor Jahangir. The St. Cecilia image now in Jaipur likely was created by artists in eighteenth-century Awadh. Yet, even with this additional information about the origins of the two objects, their routes of transmission remain obscured. How, indeed, did South Asian artists reproduce these forms and others related to them (including ducks, emperors, and camels, to name just a few), and why?

If the evidence of the St. Cecilia paintings is any indication, the vectors of image reproduction and circulation were exceedingly complex. This essay has argued that, more specifically, these images may be located in the embodied knowledge that inhered in and was conveyed-again, bodily-by court artists themselves; by the highly mobile and precarious technology of the muraqqa'; and by intermediaries, like Nandaram Pandit, who brokered the sale and gifts of album pages among South Asian and European elites over the course of the eighteenth century and after. To reckon more fully with the apparently long lives of seventeenth-century Mughal pictorial forms, we must not only attend to their origins and current locations but also address the multiple practices, technologies, and agents that bridged these domains.

Yael Rice, PhD (University of Pennsylvania), 2011, is assistant professor of art history and Asian languages and civilizations at Amherst College, Massachusetts. She specializes in the art and architecture of South Asia, Central Asia, and Iran, with a particular focus on manuscripts and other portable arts of the fifteenth through eighteenth centuries. Rice is the author of the forthcoming monograph Agents of Insight: Artists, Books, and Painting in Mughal South Asia (University of Washington Press) and articles on the Mughal manuscript workshop and the production and circulation of Persianate albums (muraqqa's) in South Asia and beyond. E-mail: yrice@amherst.edu 


\section{Notes}

Research and travel for this study were generously supported by an American Institute of Indian Studies-National Endowment for the Humanities Senior Long-term Fellowship. I am grateful to those who read and provided commentary and suggestions on earlier versions of this essay, especially Holly Shaffer, Murad Khan Mumtaz, Fatima Quraishi, the two anonymous peer reviewers, and the participants in the fall 2020 Wesleyan Renaissance Seminar.

1 Rembrandt's drawings after Mughal and other South Asian album paintings were recently the subject of a major exhibition mounted at the Getty Museum, Los Angeles, in 2018. For the exhibition catalogue, including my contribution, an essay entitled "The Global Aspirations of the Mughal Album," see Rembrandt and the Inspiration of India, ed. Stephanie Schrader (Los Angeles: Getty Publications, 2018).

2 On the Mughal and Deccani album materials that members of the Habsburg family disassembled, cut up, and mounted (with additions) in the Millionenzimmer in Schloss Schönbrunn, Vienna, see Aaron Hyman, "The Habsburg Re-Making of the East at Schloss Schönbrunn, 'or Things Equally Absurd,"' The Art Bulletin 101.4 (2019): 39-69.

3 The most famous of these peripatetic and heavily modified albums is the so-called St. Petersburg Album; see Oleg Akimushkin et al., The St. Petersburg Muraqqa: Album of Persian Miniatures of the 16th-18th Centuries and Specimens of Persian Calligraphy of 'Imād al-Hasanī (Lugano: Arch Foundation; Milano: Electa, 1996). More recent studies have addressed other Iranian albums containing Indian contents that are currently held in Russian collections. See, for example, Olga Vasilyeva, "The National Library of Russia muraqqa'-Album Dorn 489 and Its Provenance," Journal of Islamic Manuscripts 7 (2016): 66-88; and Anastassiia Alexandra Botchkareva, "Topographies of Taste: Aesthetic Practice in 18th-Century Persianate Albums," Journal18, no. 6, Albums (Fall 2018), https://www.journal18.org/ issue6/topographies-of-taste-aesthetic-practice-in -18th-century-persianate-albums/ (last accessed June 8,2021 ).

4 On the history of the Wantage Album, see Susan Stronge, Painting for the Mughal Emperor: The Art of the Book, 1560-1660 (London: V\&A Publications, 2002), 145-46.

5 The scholarship on eighteenth-century South Asian albums is voluminous. Beyond the studies cited elsewhere in this article, see also Lucian Harris, "Archibald Swinton: A New Source for Albums of Indian Miniatures in William Beckford's Collection," The Burlington Magazine 143.1179 (2001): 360-66; Chanchal Dadlani, "Transporting India: The Gentil Album and Mughal Manuscript Culture," Art History 38.4 (2015): 749-61; and Holly Shaffer, "'Take
All of Them': Eclecticism and the Arts of the Pune Court in India, 1760-1800," The Art Bulletin 100.2 (2018): 61-93.

6 Molly Emma Aitken, "Parataxis and the Practice of Reuse, from Mughal Margins to Mīr Kalān Khān," Archives of Asian Art 59 (2009): 90. For an earlier interpretation of the phenomenon of Indian painters' copying practices over time, see also Vishakha Desai, "Reflections of the Past in the Present: Copying Processes in Indian Painting," in Perceptions of South Asia's Visual Past, ed. Catherine B. Asher and Thomas R. Metcalf (New Delhi: Oxford and $\mathrm{IBH}$ and the American Institute of Indian Studies, 1994), 135-47.

7 The title of this essay deliberately invokes Elizabeth Eisenstein's important The Printing Press as an Agent of Change: Communications and Cultural Transformations in Early-Modern Europe (Cambridge and New York: Cambridge University Press, 1997), a watershed study of the technological and cultural impact of the printing press in Europe. It also nods to two recent symposia and a conference panel-conceived by András Kiséry, Hansun Hsiung, and myself-that have centered books and print as "agents of contact." 8 On this emulative paradigm, which applied not only to pictorial representations but also to calligraphy, poetry, and architecture, see Adel T. Adamova, "Repetition of Compositions in Manuscripts: The Khamsa of Nizami in Leningrad," in Timurid Art and Culture: Iran and Central Asia in the Fifteenth Century, ed. Lisa Golombek and Maria Subtelny (Leiden: Brill, 1992), 67-75; David J. Roxburgh, "Kamal al-Din Bihzad and Authorship in Persianate Painting," Muqarnas 17 (2000): 119-46; Paul Losensky, Welcoming Fighāni: Imitation and Poetic Individuality in the SafavidMughal Ghazal (Costa Mesa, CA: Mazda, 1998); and Chanchal Dadlani, From Stone to Paper: Architecture as History in the Late Mughal Empire (New Haven and London: Yale University Press, 2018), esp. chapter 1.

9 The Mughal artist 'Abd al-Samad (active ca. 1540-95) had produced his own version of the subject of fighting camels (today held in a private collection) several decades earlier. As scholars have noted previously, this subject was a favorite among the artists employed at the Persianate courts of Iran, Central Asia, and South Asia. On this subject, see Adel T. 
Adamova, "The Iconography of a Camel Fight," Muqarnas 21 (2004): 1-14, esp. 1-2.

10 Abu'l Fazl, A'in-i Akbari (Regulations of Akbar), ed. Henry Blochmann, vol. 1 (reprint, Osnabrück: Biblio Verlag, 1985), 116; and Abu'l Fazl, A'in-i Akbari, trans. C.M. Naim, in Pramod Chandra, The Tütināma of the Cleveland Museum of Art and the Origins of Mughal Painting, vol. 1 (Graz: Akademische Druck und Verlagsanstalt, 1976), 182. Whether the painting is in the hand of Bihzad, as its epigraph states, is another matter. Adamova, for example, doubts the authenticity of the inscription and its claims, and instead dates the production of the work credited to Bihzad to the 1540s; see Adamova, "Iconography of a Camel Fight," 2.

11 In her catalogue entry for the mallard page in the Morgan Read Album, Barbara Schmitz also identifies another seventeenth-century double duck composition, seemingly related to those addressed here, in the Museum of Fine of Arts, Boston (19.129). See Barbara Schmitz, Islamic and Indian Manuscripts and Paintings in the Pierpont Morgan Library (New York: Pierpont Morgan Library, 1997), 145-46.

12 I take up the subject of Mughal typological portraiture at greater length in Agents of Insight: Arts, Books, and Painting in Mughal South Asia (University of Washington Press, forthcoming).

13 Rosalind O'Hanlon, "Manliness and Imperial Service in Mughal North India," Journal of the Economic and Social History of the Orient 42.1 (1999): 64.

14 A minute inscription on the Gulshan Album page, reading 'amal-i Manohar (work of Manohar), suggests that Manohar was responsible for the production of both portraits of Madhu Singh.

15 The emphasis on contour as the locus in Mughal portraiture meant that these materials were easily transferable to other workshops. On the reliance of album painters in Golconda on tracings made from Mughal portrait models, for example, see Marta Becherini, "Effigies in Transit: Deccan Portraits in Europe at the Turn of the 18th Century," Journal18, no. 6, Albums (Fall 2018), http://www.journal18 .org/issue6/effigies-in-transit-deccan-portraits-in -europe-at-the-turn-of-the-18th-century/ (last accessed June 9, 2021).

16 Paul Connerton, How Societies Remember (Cambridge: Cambridge University Press, 1989), 72. For a late sixteenth-century source that touches on the training of painters in the Mughal manuscript workshop, see Abu'l Fazl, A'in-i Akbari, ed. Blochmann, 116-18; and Abu'l Fazl, A'in-i Akbari, trans. Naim, 182-84.

17 The movement of artists from the Mughal court to those in the suba of Awadh is addressed in J.P. Losty,
"Towards a New Naturalism: Portraiture in Murshidabad and Avadh, 1750-80," in After the Great Mughals: Painting in Delhi and the Regional Courts in the 18th and 19th Centuries, ed. Barbara Schmitz (Marg: Bombay, 2002), 34-55; and Malini Roy, "Origins of the Late Mughal Painting Tradition in Avadh," in India's Fabled City: The Art of Courtly Lucknow, ed. Stephen Markle (Los Angeles: Los Angeles County Museum of Art, 2011), 165-86.

18 On eighteenth-century copies by Jaipur artists of seventeenth-century Mughal paintings, see Shailka Mishra, "Suratkhana at Amber-Jaipur in the 18th Century: Paintings, Patronage, Practices" (PhD diss., Jawaharlal Nehru University, 2015), 303-10.

19 On the Dara Shikoh Album (British Library, London, Add.Or.3129), see Jeremiah P. Losty and Malini Roy, Mughal India: Art, Culture and Empire (London: The British Library, 2012), 124-37; Jeremiah Losty, "The Dara Shikoh Album: A Reinterpretation," unpublished article, May 2014, https://www .academia.edu/7202804/The_Dara_Shikoh_Album _A_Reinterpretation (last accessed June 11, 2021); and Jeremiah Losty, "Dating the Dara Shukuh Album," in The Mughal Empire from Jahangir to Shah Jahan: Art, Architecture, Politics, Law and Literature, ed. Ebba Koch and Ali Anooshahr (Mumbai: Marg, 2019), 246-87.

20 For example, scholars have identified around twenty folios from an album that Prince Khurram (later Shah Jahan) assembled when he was in his teens. For a brief description of this now dispersed album, see Elaine Wright, Susan Stronge, and Wheeler M. Thackston, Muraqqa': Imperial Mughal Albums from the Chester Beatty Library, Dublin (Alexandria, VA: Art Services International, 2008), 473. On the production of albums (largely inspired by Mughal precedents) at the Kachhwaha court in Amber during the seventeenth century, see Catherine Glynn, "A Rājasthānī Princely Album: Rājput Patronage of Mughal-Style Painting," Artibus Asiae 60.2 (2000): 222-64.

21 This group of roughly contemporaneous album paintings, all associated with Jahangir's patronage, includes a depiction of Jahangir seated on an hourglass throne by Bichitra (active 17th century; Freer Gallery of Art, Smithsonian Institution, Washington, DC, F1942.15a); Bichitra's double-page portraits of Jahangir and a Sufi saint (Chester Beatty Library, Dublin, In 07A.5 and In 07A.14); a depiction of Jahangir seated with Shah 'Abbas (1571-1629, r. 1588-1629), likely executed by Bishandas (active 1590-1640; Freer Gallery of Art, Smithsonian Institution, Washington, DC, F1942.16a); a depiction of Jahangir shooting a personification of poverty,

\section{ARS ORIENTALIS 51}


probably completed by Abu'l Hasan (1589-ca. 1630; Los Angeles County Museum of Art, M.75.4.28); and Abu'l Hasan's depiction of Jahangir shooting Malik 'Ambar (1548-1626; Chester Beatty Library, Dublin, In 07A.15).

22 On the history of the St. Petersburg Album, see Akimushkin, St. Petersburg Muraqqa'.

23 On album-making and copying at the Rajasthani courts in particular, see Aitken, "Parataxis and the Practice of Reuse"; and Molly Aitken, The Intelligence of Tradition in Rajput Court Painting (New Haven: Yale University Press, 2010), especially the chapter entitled "Repetition and Response: The Case of Layla and Majnun." For Lucknow, see Natasha Eaton, "Critical Cosmopolitanism: Gifting and Collecting Art at Lucknow, 1775-1797," in Art and the British Empire, ed. Tim Barringer, Geoff Quilley, and Douglas Fordham (Manchester: Manchester University Press, 2009), 189-204.

24 On a parallel phenomenon in the context of architectural patronage, see Dadlani, From Stone to Paper.

25 On Polier's activities in India, see Sanjay Subrahmanyam, "The Career of Colonel Polier and Late Eighteenth-Century Orientalism," Journal of the Royal Asiatic Society 10.1 (2000): 43-60.

26 Natalia Di Pietrantonio speculates that Polier may have acquired some of these materials on the open market. See Di Pietrantonio, "Circuits of Exchange: Albums and the Art Market in 18th-Century Avadh," Journal18 (October 2018), http://www.journal18 .org/2846 (last accessed June 11, 2021).

27 Indeed, London auction catalogues from the nineteenth century include numerous references to sales of Indian and Persian manuscripts. On the reception of album materials in eighteenth- and nineteenthcentury England, and the impulse among Europeans more generally to collect objects from India, see Maya Jasanoff, "Collectors of Empire: Objects, Conquests and Imperial Self-Fashioning," Past \& Present 184.1 (2004): 109-35; Natasha Eaton, "Nostalgia for the Exotic: Creating an Imperial Art in London, 1750-1793," Eighteenth-Century Studies 39.2 (2006): 227-50; and Emily Hannam, Eastern Encounters: Four Centuries of Paintings and Manuscripts from the Indian Subcontinent (London: Royal Collection Trust, 2018), esp. 22-35. For a fascinating account of one East India Company agent's acquisition of a South Asian album in India that later would travel to England and finally to Germany, where these materials reside today, see Harris, "Archibald Swinton."

28 Di Pietrantonio, "Circuits of Exchange."

29 According to Di Pietrantonio, the album had first been assembled in Mughal Delhi in 1750 and then later reworked under the direction of the Mughal emperor Shah 'Alam II (1728-1806, r. 1760-88, 1788-1806); see Di Pietrantonio, "Circuits of Exchange."

30 On the Morgan Library's Read Mughal Album (M.458.1-36) and a companion album known as the Read Persian Album (M.386.1-21), see Schmitz, Islamic and Indian, 111-73; and on the Shah Jahan Album, see Stuart Cary Welch et al., The Emperors' Album: Images of Mughal India (New York: The Metropolitan Museum of Art, 1987).

31 Mishra, "Suratkhana at Amber-Jaipur," 267-68.

32 Stuart Cary Welch's tantalizing reference to album pages in Jaipur's Maharaja Sawai Man Singh II Museum that bear the same imperial seal of Jahangir that also appears on the pages of the Wantage Album provides yet a further link connecting Jaipur's collections with the Wantage materials. See Welch, Emperors' Album, 26.

33 I wish to thank Walter Hakala and Tyler Williams for their help in translating this inscription.

34 Mishra, "Suratkhana at Amber-Jaipur," 311.

35 Mishra, "Suratkhana at Amber-Jaipur," 311.

36 Di Pietrantonio, "Circuits of Exchange." For an illuminating discussion of the purchase of Mughal paintings, muraqqa's, and other manuscripts in the marketplace for Jaipur royals during the eighteenth and nineteenth centuries, see Mishra, "Suratkhana at Amber-Jaipur," 93-124.

37 For a brief history of the Wantage Album at the Victoria and Albert Museum, see Stronge, Painting for the Mughal Emperor, 145-46.

38 Stanley Clarke, Indian Drawings: Thirty Mogul Paintings of the School of Jahängir (17th Century) and Four Panels of Calligraphy in the Wantage Bequest (London: H.M. Stationery Office, 1922), 4.

39 Moti Chandra, The Technique of Mughal Painting (Lucknow: U.P. Historical Society, 1949), 79-85. Chandra here describes what he identified as late eighteenthcentury paintings in the Wantage Album as "fakes" (80), whereas he terms the seventeenth-century paintings in the same collection as "genuine" (81).

40 Rosemary Crill, "A Lost Mughal Miniature Rediscovered," V\&A Album 4 (1985): 330-36; and Welch, Emperors' Album, 26, 30 n. 55.

41 Crill, "A Lost Mughal Miniature Rediscovered," 336.

42 The Wantage Album folios bearing seventeenthcentury Mughal paintings and impressions of Jahangir's seal on their reverses include IM.111-1921, IM.112-1921, IM.117-1921, IM.118-1921, IM.120-1921, IM.121-1921, IM.123-1921, IM.124-1921, IM.134-1921, IM.135-1921, IM.136-1921, IM.137-1921, IM.138-1921, and IM.139-1921. Note, too, the 
existence of another album folio-today residing in the Museum of Islamic Art, Doha-that bears Nandaram Pandit's seal impression on one side and Jahangir's seal impression on the other. The page with Nandaram Pandit's seal includes a painting by Farrukh Beg (ca. 1547-after 1615), which is dated AH 1024 (1615). Both sides of the folio, including the borders showing the seal impressions, are reproduced in Stuart Cary Welch, India: Art and Culture, 1300-1900 (New York: Metropolitan Museum of Art, 1985), 222-23.

$43 \mathrm{See}$, for example, the calligraphic side of album folio IM.113-1921 as well as IM.119A-1921, the border decorations of which almost certainly were completed in the eighteenth or early nineteenth century. Many of the other stamped pages bear border decorations that likely date to the 1630s, again pointing to the use of the seal impression on album pages that post-date Jahangir's own reign.

44 See Crill, "A Lost Mughal Miniature Rediscovered"; as well as Welch, Emperors' Album, 26, 48.

45 The letter is translated in full in Claude Martin, Man of the Enlightenment in Eighteenth-Century India: The Letters of Claude Martin, 1766-1800, ed. and trans. Rosie Llewellyn-Jones (New Delhi: Permanent Black, 2003), 82.

46 The manuscript in question, which today bears the shelfmark IO Islamic 1791, is recorded as cat. no. 2260 in Hermann Ethé, Catalogue of Persian Manuscripts in the Library of the India Office (Oxford: Printed for the India office by H. Hart, 1903), 1234.

47 The date recorded in Nandaram Pandit's seal presumably provides the year in which at least some of the album pages came into his possession. While a cataloguer at the Victoria and Albert Museum has read the date as AH 1161 (1748), Jake Benson has read it instead as AH 1151 (1738-39). What remains to be explained is how paintings made during the late eighteenth century were mounted on album folios bearing a much earlier dated seal impression.

48 The pages with Nandaram Pandit's seal include IM.110-1921, IM.111-1921, IM.112-1921, IM.113-1921, IM.114-1921, IM.115-1921, IM.116-1921, IM.117-1921, IM.118-1921, IM.119-1921, IM.120-1921, IM.121-1921, IM.123-1921, IM.124-1921, IM.134-1921, IM.135-1921, IM.136-1921, IM.137-1921, IM.138-1921, and IM.139-1921.

49 Annabel Teh Gallop, "The Genealogical Seal of the Mughal Emperors of India," Journal of the Royal Asiatic Society 9.1 (1999): 88. Citing Welch (Emperors' Album, 26), Gallop notes that the collections of the Maharaja Sawai Man Singh II Museum, Jaipur, also hold album folios that bear Jahangir's seal impressions; see Gallop, "Genealogical Seal," 88 n. 20. Unfortunately, Welch has not identified the shelfmark for the Jaipur album folios in question.

50 On Mughal painters in Delhi and their involvement in both imperial and colonial manuscript projects during the early nineteenth century, see Yuthika Sharma, "In the Company of the Mughal Court: The Delhi Painter Ghulam Ali Khan," in Princes and Painters in Mughal Delhi, 1707-1857, ed. Yuthika Sharma and William Dalrymple (New Haven and London: Asia Society Museum with Yale University Press, 2012), 41-52; Yuthika Sharma, "Art in Between Empires: Visual Culture and Artistic Knowledge in Late Mughal Delhi, 1748-1857" (PhD diss., Columbia University, 2013); and Yuthika Sharma, "Village Portraits in William Fraser's Portfolio of Native Drawings," in Portraiture in South Asia since the Mughals: Art, Representation and History, ed. Crispin Branfoot (London and New York: I.B. Tauris, 2018), 199-220. 